\title{
開水路急拡部の水理学的性状に関する研究 \\ FLOW BEHAVIOURS AT SUDDEN EXPANSIONS OF OPEN CHANNEL
}

\author{
石 原 藤次郎*・志 方 俊 之** \\ By Tojiro Ishihara and Toshiyuki Shikata
}

\begin{abstract}
要 旨 本文は, 開水路急変部における遷移流の 水理学的特性を明らかにする第一段階として, 幅が急激 に拡大する水路において, 開水路流れが示す各種の水理 学的特性, すなわち遷移現象の分類, 遷移水面形状, エ ネルギー損失, 流速分布, およびはく離領域について理 論的および実験的に考察を加えたものである。

流れは, 開水路急拡部よりはく離し，しかもこのはく 離領域は流れの水理学的性格にいちじるしい影響を与え る。ここでは開水路急桩部における流れは拘束された流 れの場の噴流と類似の現象であると考えて, 実験的に得 られる流れの挙動より一つのモデルを作り, 開水路急拡 部における流れの特性を取り扱った。この結果, 水路側 壁の拘束効果を示す一つの実験的パラメーター (confine parameter) によって, 流速分布やはく離領域の性格が 決定されることが明らかにされた。
\end{abstract}

\section{1. 緒 言}

水路形状や境界特性の急激な変化をともなう開水路を 通る流れは, 一般に急激かつ複雑な変化を示し, その力 学的関係を解析的に解くことのむずかしい急変流であ る。

従来, 急変流の種々の現象はむしろ経験的かつ実用的 に解析されてきたが，この研究は開水路の急拡部を通る 流れを急変流の代表的な問題としてとり上げ，系統的な 実験によって, その水理学的解析法を一歩前進せしめよ うとしたものである。

水路の急変部に扔ける水理学的性状に関する研究は, 急変部におけるエネルギー損失を最小にするための最適 遷移条件を求めることに端を発した。しかしながら，こ れらの研究はその大部分が管路の流れに関するものであ り，しかも急変部近傍の局所的な水理現象を取り扱った ものは数少なく，十分に解明されていない。近年になっ て, 上うやく開水路についても, その研究が行なわれる ようになったが，これらはその目的执よび，取り扱う流

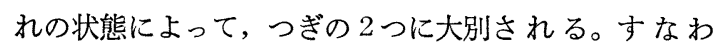
ち, (i ) 急変部を通過する射流の水面形状に関する研 究 $^{11,2)}$, (ii) 急変部を通過する常流のエネルギー損失 に関する研究 ${ }^{32,4)}$, この他, 移動床水路における急变部

* 正会員 工博 京都大学教授 工学部土木学科

** 学生会員 京都大学大学院学生
近傍の洗掘現象に関する実験的研究も並行して行なわ れている5”。本研究はむしろ後者に属するものであり, とくに急変部近傍の局所的水理現象に着目して詳細な実 験を行ない, この部分のエネルギー変換機構の解明を取 り扱おうとするものである。そのためには，(1) 遷移の 分類, (2) 遷移水面形状, (3) エネルギー損失の評価, （4）流速分布の特性，（5）はく離領域の特性について十 分な検討を加えなければならない。しかし，急変部近傍 の流れはきわめて複雑で, 現在の水理実験技術によって 詳細な計測を行なうことはなかなかむずかしい。したが って, 何らかの形でこの流れの示す挙動をモデル化する とともに, その解析結果の実際問題への適用をはかるこ とが望ましい。このような観点から，本文では，まず一 次元運動量解析法によって遷移を分類し，それにともな うエネルギー損失を推定するとともに，急拡部における 流れの細部構造について，その特性を示そうとするもの である。

\section{2. 開水路急拡部における流れの遷移現象}

\section{（1）開水路急拡部における遷移現象とその分類}

急拡部の流れを特徴づけるものは, 水路境界面からの 流れのはく離にあるといえる。従来からの多くの実験に よれば, 拡大角 $\theta$ (図一1 参照) が $8 \sim 10^{\circ}$ ではく離現 象が生起し, $\theta>30^{\circ}$ でははく離領域の特性が $\theta$ によ。 て変化せず，ほぼ一定の状態になることが明らかにされ ている(6),7)。したがって， $\theta=90^{\circ}$ の急拡部を対象として 議論することによって, 各種の急拡部に生ずる遷移現象 を代表し得ると考え, 以下ではすべて $\theta=90^{\circ}$ の急拡部 を取り扱うものとする。

図-1 Sketch of a sudden expansion.

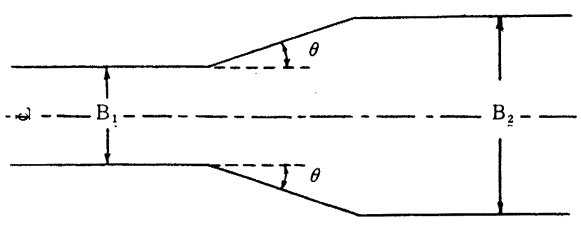

開水路流れの遷移現象は, 水路の幾何学的形状・粗度 ・勾配などの水路自体の特性と流量・流れの状態・下流水 位など流れ自体の特性によって決定される。すなわち， 正勾配水路の流れについて，与えられた水路の幾何学的 


\begin{tabular}{|c|c|c|c|c|}
\hline \multicolumn{3}{|c|}{ 表一1（a） } & \multicolumn{2}{|c|}{ 表-1（b） } \\
\hline case & 上流側水路 & 下流 側水路 & case & $\begin{array}{l}\text { Zone or or } \\
\text { Line }\end{array}$ \\
\hline 1 & 緬勾配水路 & 他の縒勾配水路 & 1 & Zone $C$ \\
\hline 2 & 緩勾配水路 & 限界勾配水路 & 2 & Line $b$ \\
\hline 3 & 緩勾配水路 & 急勾配 水 路 & 3 & Zone $B$ \\
\hline 4 & 限界勾配水路 & 緩勾配 水路 & 4 & Line $a^{\prime}$ \\
\hline 5 & 限界勾配水路 & 他の限界勾配水路 & 5 & Point $p$ \\
\hline 6 & 限界勾配水路 & 急勾配 水路 & 6 & Line $a$ \\
\hline 7 & 急勾配水路 & 䌅勾配 水路 & 7 & Zone $D$ \\
\hline 8 & 急勾配水路 & 限界勾配水路 & 8 & Line $b^{\prime}$ \\
\hline 9 & 急勾配水 路 & 他の急勾配水路 & 9 & Zone $A$ \\
\hline
\end{tabular}

形状および流量

によって，一義

図-2 Relation between critical bed slope and discharge.

的に決定される 限界水深を用い て, 流れの遷移 状態を示す基本 の水路形式が表 -1(a)のよう に分類される。

いま，この研 究に用いた水路 形状 $\left(B_{1}=15\right.$ $\mathrm{cm}, B_{2}=30 \mathrm{~cm}$, $n=0.011$ ) に対

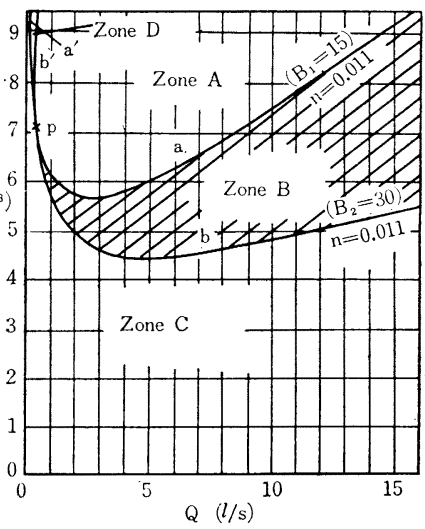

する限界勾配 $i_{c}$ を流量 $Q$ の関数として表わし，これ らの分類を示すと, 図一2 および 表一1 (b) のようにな る。この図から明らかなように，同じ底勾配であっても， 流量の変化によって上下流水路の水理学的特性はいろい ろの組み合わせを生じ，これらの分類を考慮して急拡部 の遷移水面形状を論ずる必要がある。C. Jaeger ${ }^{8)}$ は上 に示した急拡部における遷移形式を, 接近流の Froude 数 $\left(F r_{1}\right)$ と上下流の水樑比 $\left(\phi=h_{2} / h_{1}\right)$ とを用いて, 表 -2 に示すような 4 形式に分類した。ここに， $\beta_{*}$ : 水路 幅拡大比 $\left(=B_{2} / B_{1}\right)$ 。

\begin{tabular}{c|cc|cc|c|c}
\multicolumn{7}{|c|}{ 表一2 } \\
\hline & 上 & 流 & 下 & 流 & $F r_{1}$ & 水 深 比 \\
\hline 1 & 常 & 流 & 常 & 流 & $F r_{1}<1$ & $\phi>1$ \\
2 & 常 & 流 & 射 & 流 & $F r_{1}<1$ & $\phi<1 / \beta_{*}$ \\
3 & 射 & 流 & 常 & 流 & $F r_{1}>1$ & $\phi>1$ \\
4 & 射 & 流 & 射 & 流 & $F r_{1}>1$ & $\phi<1 / \beta_{*}$ \\
\hline
\end{tabular}

しかしながら，これは急桩部近傍の局所的な水面形の 挙動の詳細および下水流深の影響などを考慮に入れてい ないため，実際の現象を説明するには不十分であり，詳 細な実験によって局所的現象を明らかにする必要があ る。

\section{（2）遷移にともなう流れの局所的挙動}

急拡部をはさんで上下流水路が十分に長いと，急拡部 より離れた上下流の水深は，その流量に対するそれぞれ の等流水深に近づくから，急拡部近傍の局所的な遷移水
図-3 Transition profiles through a sudden expansion.

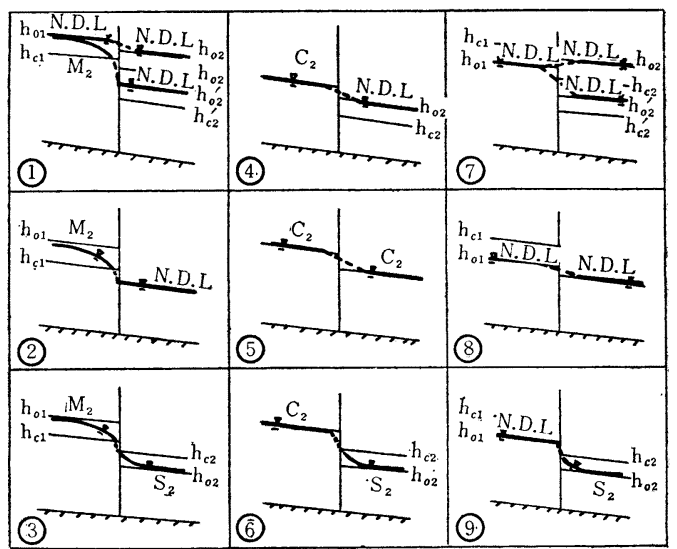

面形状を除いて，一般的な水面形の定性的挙動が示され る。図一3 は表一1（a）にあげた水路の分類について， これらの水路にあらわれる水面形を示したものである。 しかしながら，実際にあらわれる急拡部近傍の流れは， 水面の急激な低下と同時に水路境界からのはく離をとも なう局所的に複雑な遷移水面形状となることが予想され る。著者らは, 各種の流量 $(4 \sim 30 \mathrm{l} / \mathrm{sec})$ と勾配 $(2 \sim 7 \times$ $\left.10^{-3}\right)$ において下流を等流水深にした場合の遷移水面形 に関して実験を行なった。これらの結果から定性的につ ぎのようなことが明らかにされる。すなわち, 流量や勾 配のいかんにかかわらず，急拡部の直下流では射流状態 で交差波の不安定な波状水面が形成され，それぞれ下流 水深に接続する。また, 底勾配や流量によって, 跳水位 置が変化することは明らかで ある。図-4 は著者らの実験 で得た遷移水面形を例示した ものである。

さらに下流水深を等流水深 からせき上げた場合について 実験を行なうと，下流水深が ある水深 (以下, これを臨界 下流水深と呼年）以上に上昇 すると, 急拡部近傍の遷移は すべて常流となる。すなわち 緩勾配開水路急拡部の流れの 遷移形状は，臨界下流水哚を 境として, 常流 $\rightarrow$ 射流 $\rightarrow$ 常 流と常流 $\rightarrow$ 常流とに大別され ることが実験的に確かめられ る。図一5 は著者らの実験に よって得られた遷移水面形の 一例を示したものであるが， 便宜上, 下流水深が臨界下流 水深以上のものを常流遷移,

\section{図-4}

Typical transition profiles through the sudden expansion.

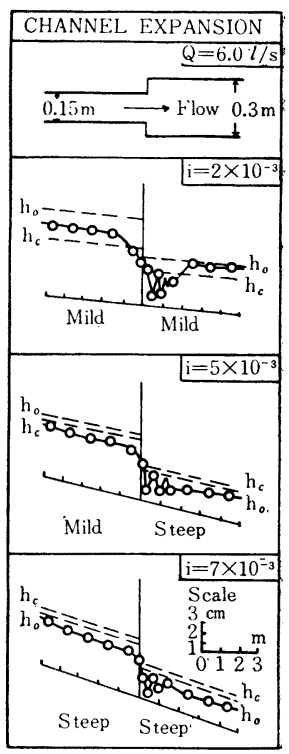


図-5 Typical profiles of submerged and shooting transitions:

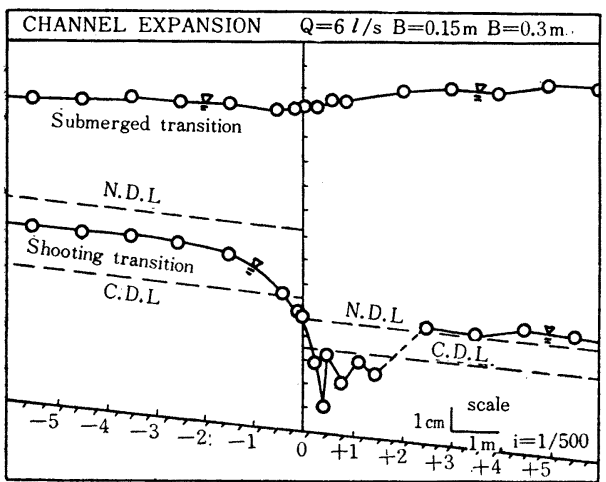

それ以下のものを射流遷移と呼ぶことにする。しかしな がら,下流水深が臨界下流水深となる場合には, 急拡部近 傍の流れは限界流に近い不安定な状態にあるため, 射流 遷移と常流遷移とは臨界下流水深を境にして明瞭に区別 されるわけではなく, その間には何らかの遷移領域が存 在する。いまこれをかりに不安定遷移とよぶこととする。

\section{3. 緩勾配開水路の急拡部における遷移の 一次元解析}

開水路の急拡部や急縮部としての不連続部では, 渦や 波状水面の形成などによって，大きい内部エネルギーの 変化がおこる。しかしながら，この損失を評価すること は非常に困難であるから，たとえ一次元解析法を適用す るにしても, エネルギー方程式より,むしろ運動量方程 式を解析手段として用いる方が適切である。とくに，こ の種の問題では, 境界面における外力の摩擦損失は内部 エネルギーの損失に比較して重要でなく，実用的見地か らは無視してよいであろう。

\section{(1) 急拡部における遷移}

図一6 に示す急拡部をもつ緩勾配長方形断面水路にお ける流れについて, 断面I と断面II の間の運動量方程式 および連続式は，それぞれ

$$
\frac{1}{2} \lambda_{1} \rho g B_{1} h_{1}{ }^{2}+\rho B_{1} h_{1} \eta_{1} u_{1}{ }^{2}+W \sin \theta
$$

図-6 Surface profile of shooting transition assumed in the analysis.

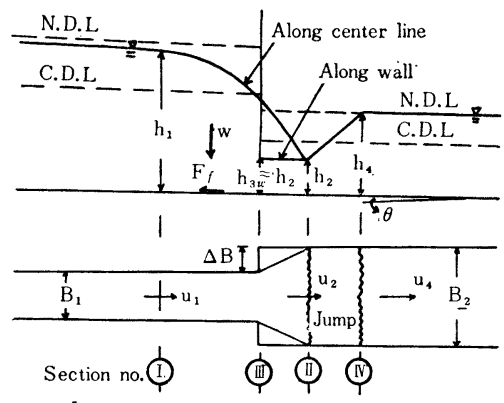

$$
\begin{aligned}
& +\frac{1}{2} \lambda_{3} \rho g 2 d B h_{3} w^{2} \\
& =\frac{1}{2} \lambda_{2} \rho g B_{2} h_{2}^{2}+\circ B_{2} h_{2} \eta_{2} u_{2}{ }^{2}+F_{f} \\
& B_{1} u_{1} h_{1}=B_{2} u_{2} h_{2}=B_{2} u_{4} h_{4}
\end{aligned}
$$

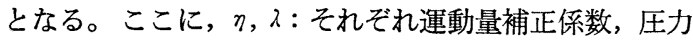
分布係数, $W$ : 断面 I II 間の流体の重量, $F_{f}$ : 境界 面に働らく表面摩擦抵抗, $\rho$ : 流体の密度, $g$ : 重力の加 速度, $h:$ 水深, $u:$ 平均流速, $B:$ 水路幅, $\theta:$ 水路底 勾配，なお添字 $1 ， 2$ はそれぞれ断面 I, II における值 を表わす。いま簡単のため, 水路を緩勾配とすると，水 の重量の影響は無視せられ，またこのような急拡部では 表面摩擦抵抗が小さいと考えると, これらの両式からつ ぎの式 (3-3) が得られる。

$$
\begin{aligned}
\lambda_{1} & +2 \eta_{1} \frac{u_{1}{ }^{2}}{g h_{1}}+\lambda_{3}\left(\beta_{*}-1\right)\left(\frac{h_{3 w}}{h_{1}}\right)^{2} \\
& =\lambda_{2} \beta_{*}\left(\frac{h_{2}}{h_{1}}\right)^{2}+2 \frac{\eta_{2}}{\beta_{*}} \frac{u_{1}{ }^{2}}{g h_{1}} \frac{1}{\left(h_{2} / h_{1}\right)}
\end{aligned}
$$

ここに, $\beta_{*}=B_{2} / B_{1}:$ 水路幅拡大比

Jaeger $^{8)}$ は急拡部の流れは常流遷移であるとして $h_{3 w}=h_{1}$ とおいているが，著者らの実験によれば，図一 6 に示したような射流遷移では,

$$
h_{3 w} \doteqdot h_{2}
$$

とおく方がむしろ適切である。いま，簡単のために $\eta_{1}=$ $1.0, \lambda_{1}=\lambda_{3}=1.0$ とし, $u_{1}{ }^{2} / g h_{1}=F r_{1}{ }^{2}, h_{2} / h_{1}=\phi$ とおく と,

$$
F r_{1}^{2}=\frac{\phi\left[1-\phi^{2}\left\{\left(\lambda_{2}-1\right) \beta_{*}+1\right\}\right]}{2\left\{\frac{\eta_{2}}{\beta_{*}}-\phi\right\}},\left(\phi<\frac{\eta_{2}}{\beta_{*}}\right)
$$

さらに $\lambda_{2}=\eta_{2}=1.0$ とおくと,

$$
F r_{1}{ }^{2}=\frac{\phi\left(1-\phi^{2}\right)}{2\left(\frac{1}{\beta_{*}}-\phi\right)},\left(\phi<\frac{1}{\beta_{*}}\right)
$$

が得られる。これは $\beta_{*}$ をパラメーターとする双曲線群 となる。同様にして常流遷移に対しては式 (3-7) が得ら れる。

$$
F r_{1}{ }^{2}=\frac{\beta_{*} \phi\left(1-\phi^{2}\right)}{2\left(\frac{1}{\beta_{*}}-\phi\right)},(\phi \geqq 1)
$$

\section{（2）臨界下流水深}

前節で述べた常流射流および不安定遷移の問題は，急 拡部近傍の局所的遷移現象に対する下流水深の影響を示 すものといってよいから，常流遷移の場合の式 (3-7) を 下流の水理条件を用いて書きなおすと，

$$
\begin{aligned}
& f(\phi)=2 \beta_{*} F r_{2}{ }^{2} \phi^{3}-\left(1+2 F r_{2}{ }^{2}\right) \phi^{2}+1=0, \\
& (\phi \geqq 1)
\end{aligned}
$$

となる。ここに, $F r_{2}=u_{2} / \sqrt{g h_{2}}$ は下流水深に対する Froude 数である。この式 (3-8) で与えられる関数 $f(\phi)$ は, 


$$
\left.\begin{array}{l}
\phi=0 \\
\phi=\frac{1+2 F{r_{2}}^{2}}{3 \beta_{*} F r_{2}{ }^{2}}
\end{array}\right\}
$$

においてそれぞれ極大值, 極小值をもつ 3 次曲線であ る。いま式 (3-8) の根をそれぞれ， $\phi_{1}, \phi_{2}$ および $\phi_{3}$ と すると, 3 次方程式の根の一般的性質より, 一根 $\phi_{3}$ は 負の実根となり,この場合物理的意味を持たない。他の 2 根 $\phi_{1}, \phi_{2}$ は $\beta_{*}$ と $F r_{2}$ の関係によって表一3のよう に分類される。いま問題となるのは $\phi_{1}, \phi_{2}$ がともに正の 実根の場合であって， $\phi_{1}, \phi_{2}$ は一定の下流水理条件に対 する接近流の 2 つの流れの状態を与え， $\phi_{1}>\phi_{2}$ とすれ ば， $\phi_{1}$ は射流， $\phi_{2}$ は常流の水深に対忘する。したがっ て常流遷移から不安定遷流へ変化する臨界下流条件は $\phi_{1}=\phi_{2}$ となる等根を持つ場合で, 式 (3-8) および式 (3-9) から,

$$
27 \beta_{*}^{2} F r_{2}{ }^{4}-\left(1+2 F r_{2}^{2}\right)^{3}=0
$$

で与えられる。

\begin{tabular}{|c|c|c|c|c|c|c|c|c|c|}
\hline & \multicolumn{3}{|c|}{$\phi_{1}$} & \multicolumn{3}{|c|}{$\phi_{2}$} & \multicolumn{3}{|c|}{$\phi_{3}$} \\
\hline 1 & 実 & 根 & (正) & 実 & 根 & (正) & 実 & 根 & （負） \\
\hline 2 & & 等 & & & (I) & & 実 & 根 & （負） \\
\hline 3 & 虚 & & 根 & 虚 & & 根 & 実 & 根 & （負） \\
\hline
\end{tabular}

$$
\text { 表-3 }
$$

これとまったく同様にして求めた射流遷移の臨界下流 条件は,

$$
27 \beta_{*}^{4} F r_{2}^{4}-\left(1+2 \beta_{*} F r_{2}^{2}\right)^{3}=0
$$

となる。これらを一括してそれぞれの遷移の関係を図示 すると, 図一7 のようになる。

\section{(3) エネルギー損失係数}

開水路の急拡部における形状損失水頭は，DarcyWeisbach の表示によれば,

$$
h_{l}=\zeta \frac{u_{2}^{2}}{2 g}
$$

である。ところが開水路流れでは管水路の場合と異な り，流れの状態によってエネルギーの損失機構が大きく 変化し, 常流遷移では流れの不連続面に生ずる渦による

図-7 Critical downstream coditions.

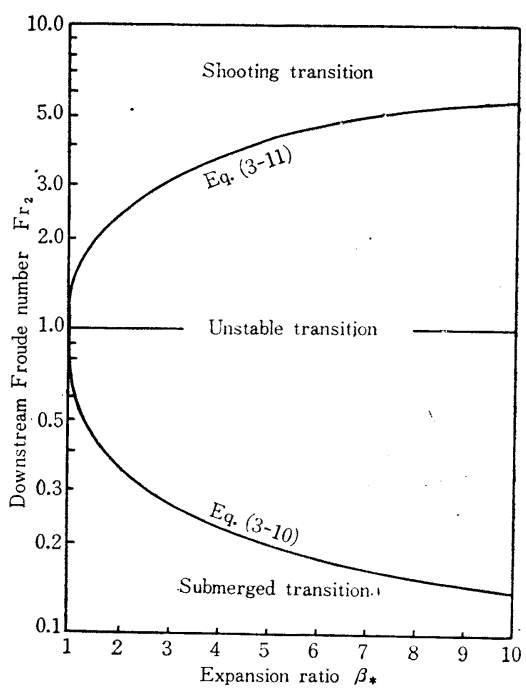

エネルギー損失が卓越し, 射流遷移では衝撃波面の形式 とそれに続く跳水とによるエネルギー損失が主要なもの となる。

急拡部における流れのエネルギー方程式は, 水路底勾 配が小さいとき，図一6 を参照して，

$$
h_{f}+h_{l}=\left(z_{1}-z_{2}\right)+\left(h_{1}-h_{2}\right)+\left(\alpha_{1} \frac{u_{1}^{2}}{2 g}-\alpha_{2} \frac{u_{2}^{2}}{2 g}\right)
$$

のようになる。ここに, $h_{f}$ : 摩擦損失水頭, $h_{l}$ : 形状損 失頭, $z$ : 基準線からの高さ， $\alpha$ : エネルギー補正係数。 いま簡単のため, 水路底勾配と摩擦損失の項を省略す ると, 式 (3-12) および (3-13) から次式が得られる。

$$
\zeta=\frac{\alpha_{1} \beta_{*}^{2} F r_{2}^{2} \phi^{3}-\left(2+\alpha_{2} F r_{2}^{2}\right) \phi+2}{F r_{2}{ }^{2} \phi}
$$

さきに述べたように，常流遷移と射流遷移とでは損失 係数が異なる值を示すと考えられるから，それらをそれ ぞれの臨界下流水深について求めると, 常流遷移につい ては式 (3-9)，(3-10) および (3-14) から,

同様に射流遷移については,

$$
\zeta_{s c}=\frac{\alpha_{1}\left(1+2 \beta_{*} F r_{2 s}{ }^{2}\right)^{3}-9 \beta_{*}^{2} F r_{2 s}^{2}\left(1+2 \beta_{*} F r_{2 s}{ }^{2}\right)\left(2+\alpha_{2} F r_{2 s}{ }^{2}\right)+54 \beta_{*}^{4} F r_{2 s}{ }^{4}}{9 \beta_{*}^{2} F r_{2 s}{ }^{4}\left(1+2 \beta_{*} F r_{2 s}{ }^{2}\right)}
$$

となる。ここに, $F r_{2 t}, F r_{2 s}$ はそれぞれ常流遷移および 射流遷移の臨界下流水深に対する Froude 数である。 図一8 に示す実線は以上の各式を用いて計算したもので あるが，簡単のため，エネルギー補正係数 $\alpha_{1}, \alpha_{2}$ をと もに 1.0 としている。図一8 から, 急抾部におけるエネ ルギー損失係数 $\zeta$ は, 下流の Froude 数 $F r_{2}$ によって 大きく変化することがわかる。すなわち，Fr $F_{2}$ の増大と ともに, 常流遷移では $ら$ が増大し, 射流遷移では逆に減 少している。また同一の $F r_{2}$ に対して拡大比 $\beta_{*}$ が増
大すると, $\zeta$ が急激に増大するという従来から指摘され た事実 ${ }^{4)}$ 確かめることができる。ここで注意すべき点 は, 射流遷移におけるエネルギー損失は, 式 (3-12) で 表わされる形状損失水頭に加えて跳水によるエネルギー 損失を考慮しなければならないことである。

\section{(4) 実験結果とその考察}

前節で述べた遷移の分類方法および一次元解析法の妥 当性とその限界とを検討するために, 一連の実験を行な った。 
图 8 Coefficient of energy loss due to sudden expansion.

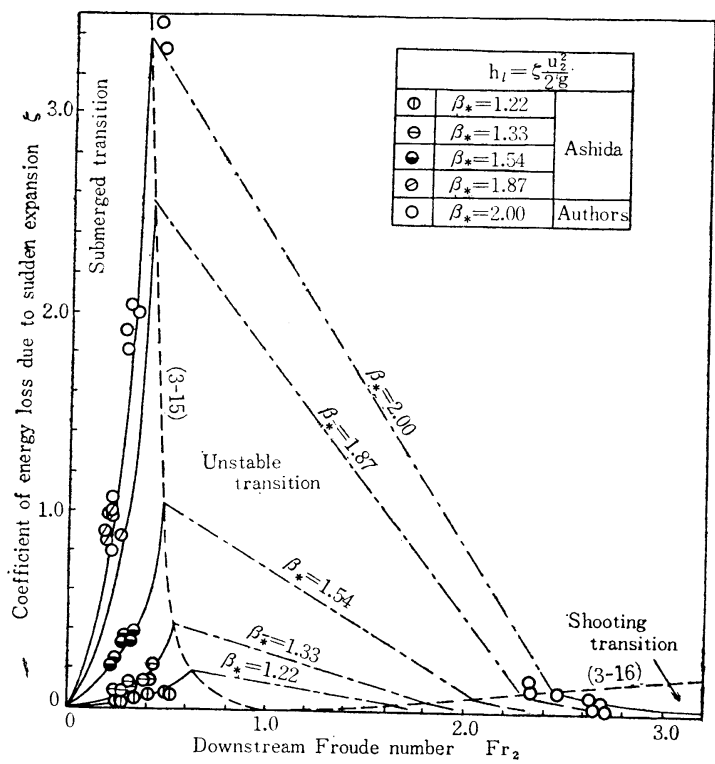

図-9 Schematic view of flume.

EXPANSION

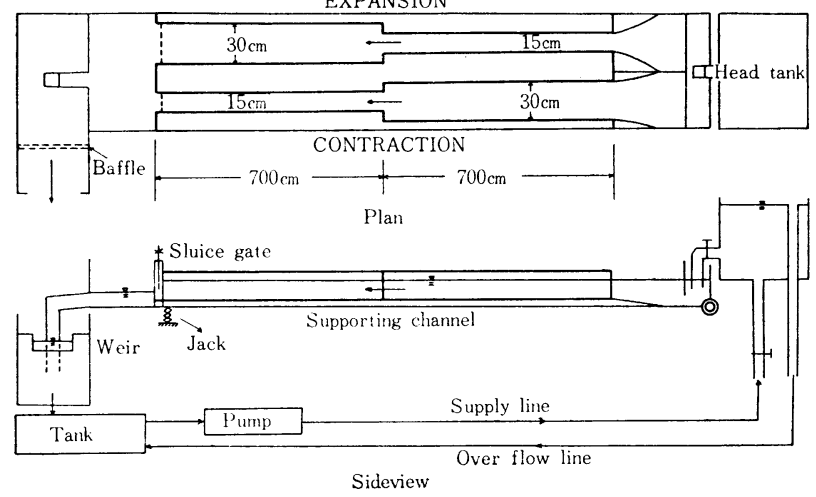

a）実験装置および実験方法 実験水路は図一9に 示す長さ $14 \mathrm{~m}$ (中央に急拡部・急縮部を設置), 哚さ $20 \mathrm{~cm}$, 水路幅 $15 \mathrm{~cm}$ および $30 \mathrm{~cm}$ の長方形断面水路 である。勾配は可変であって, 図一2 に示した， A, B, Cの領域に対応させるため, それぞれ $7 \times 10^{-3}, 5 \times 10^{-3}$, $2 \times 10^{-3}$ の 3 種類について実験を行なった。安定した接 近流を得るために水路上流端に漸変遷移部を取り付け, また下流水位の調節は水路下流端に設置した可動ぜきに よって行ない，必要な下流 Froude 数 $F r_{2}$ を与えた。実 験流量の範囲は 4 20 l/sec である。実験水路はラッカ 一塗装の木製水路で，その粗度としては水面形の実測結 果から Manning の粗度係数 $n=0.011$ (m-sec 単位)を 採用した。水深の測定にはポイント ゲージを用い，水 面変動のいちじるしい部分では, 白金抵抗線水位計とぺ ンオッシログラフによって平均水深を測定した。

b）遷移水面形 急拡部の遷移水面形はすでに図一 4 にその一例を示したが，一連の実験結果を前節の一次
元解析法によって整理すると図一10 のようになる。こ の図から，（i）下流水路が十分長い場合には，その水 深は等流水深に漸近し, 前節に述べたように射流遷移と なって $F r_{1}$ と $\phi$ との関係は式 (3-6) にしたがう。(ii) 下流水位を徐々にせき上げて $F r_{2}$ を小さくしていくと， $\phi$ が増大するが， $F_{r 1}$ 注変化しない。これは急拡部にな お支配断面が存在し，下流の影響が上流に伝播していな いことを示している。しかしながら，支配断面の下流に おける水面形は不安定な波状水面をなし，いわゆる不安 定遷移に属するものである。（iii）さらに，下流水位を せき上げると，下流の影響が上流に伝わり，Fr $r_{1}$ は急激 に減少して常流遷移を示す式 (3-7) にしたがうことがわ かる。このように実際に現われる遷移水面形は, 図一6 に示したような簡単なモデルについて得られた解析結果 とほぼ一致し，とくに図一7において $\beta_{*}=2$ の臨界下 流水深に対する Froude 数は $F r_{2 t}=0.37$ となり, 図 -10 に示した実験結果とよく一致している。

c) エネルギー損失係数 本実験 $\left(\beta_{*}=2\right)$ によって 図-10 Relation between $F r_{1}$ and $\phi$.

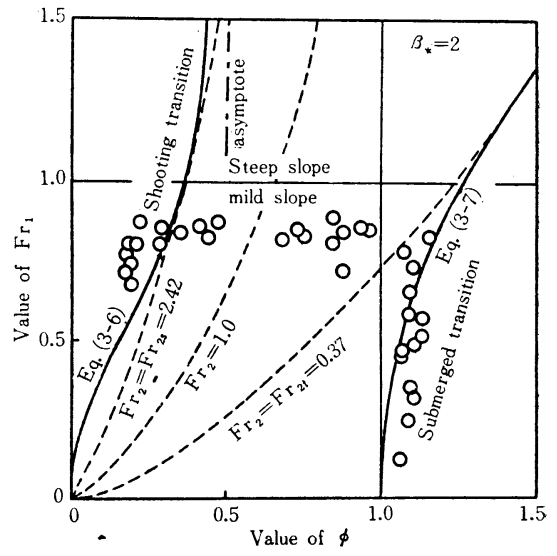

図-11 Evaluation of head loss.

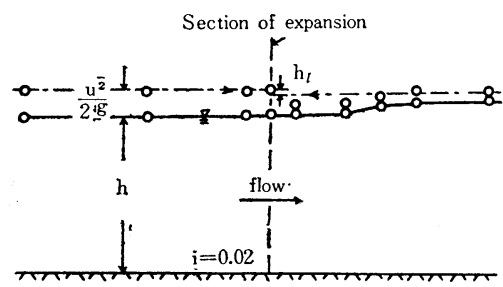

得られた結果および従来の実験結果 ${ }^{4}$ は，図一8にプロ ットしたとおりである。この場合, 損失水頭 $h_{l}$ は図一 11 に示すような方法で求められたものである。これらの 図より，簡単な仮定のもとに得られた式 (3-14), (3-15) および (3-16) の関係が実際の流れをよく説明し得るこ とがわかる。

また急拡部におけるエネルギーの形状損失係数に関し てつぎのことが明らかとなった。（i ）常流遷移では損 失係数 $\zeta$ は $F r_{2}$ の増加とともに増大し, 臨界下流水深 
に対する Froude 数 $F r_{2 t}$ に近づくにしたがって急激に 増大する。Formica ${ }^{3)}$ は $\beta_{*}=1.73$ の水路を用いて実験 $(Q=15.6 \sim 52.5 l / \mathrm{sec})$ を行ない，その結果を，

$$
h_{l}=\zeta_{0}{ }^{\prime} \frac{\left(u_{1}-u_{2}\right)^{2}}{2 \mathrm{~g}}
$$

と表わし，損失係数 $\zeta_{0}^{\prime}$ は流量のいかんにかかわらず一 定の值 $\zeta_{0}{ }^{\prime}=0.82$ を示すと結諭した。しかしながら，式

(3-12) に対すると同样な計算を行なうと,

$$
\zeta_{0}{ }^{\prime}=\frac{2(1-\phi)+F r_{2}{ }^{2} \phi\left(\alpha_{1} \beta_{*}{ }^{2} \phi^{2}-\alpha_{2}\right)}{F r_{2}{ }^{2} \phi\left(\beta_{*} \phi-1\right)^{2}} \ldots \ldots
$$

となり，流量による $0_{0}^{\prime}$ の変化を考えるよりむしろ $F r_{2}$ による変化を考えるのが妥当であることがわかる。 このことから Formica の実験は実験流量を変えてもほ ぼ同様な $F r_{2}$ のもとで行なわれたものと推測される。 (ii) 拡大比 $\beta_{*}$ が増大するにつれて実測值が理論值か ら離れるのは, エネルギー補正係数 $\alpha_{1}=\alpha_{2}=1.0$ という 大きい仮定によるものと考えられるが，この実験のみで 十分な説明をすることは困難である。(iii) 不安定遷移 の領域における $F r_{2}$ の範囲では, いわゆる波状跳水と なり, 水樑の測定が困難で比エネルギーの評価が容易で はなく, 実験值は記入されていない。（iv）射流遷移で は流速が増大するにつれて, 損失水頭 $h_{l}$ 自体は増大す るが，下流の速度水頭 $u_{2}^{2} / 2 g$ も増大するから逆に 6 の 值は減少する。しかしながら，Fr $r_{2}$ が大きくなると， $\alpha_{1}=\alpha_{2}=1.0$ の仮定が妥当性を失い, 実測值は理論值よ り小さくなる。ここで注意すべきことは, 前にも述べた ように射流遷移の損失水頭には跳水による損失水頭が加 えられていないことである。したがって遷移にともなう 損失水頭を論ずる場合には, 式 (3-12) に跳水による損 失を加えて形状損失を考えなければならない。

一般に急拡部下流に生ずる跳水は複雑で, 跳水の上下 流における運動量関係を求めることが困難である。図一 12 は本実験によって得られた水深比と Froude 数との 関倸を示したものであるが，実測值は非常にばらついて

図-12 Relation between $h_{4} / h_{2}$ and $F r_{2}$ いる。これ for hydraulic jump in downstr- は側壁によ eam charmel.

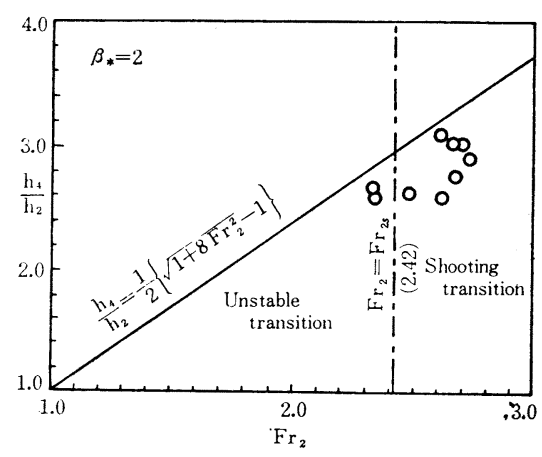
る流れの反 射の状態が Froude 数 によって異 なるため， 上流側水深 $h_{2}$ を規定 する事が困 難となるか らである。 なお，図一

12 の実測值は $h_{2}$ として単純な断面平均水深を用いて整 理したものである。

\section{4. 急拡部における常流遷移流の流速分布}

\section{(1) 概 説}

急拡部における流れの最大の特徴は, 水路壁面から流 れがはく離することである。急拡部の両側に形成される はく離領域内では, 流体は複雑な洞運動を行なってい る。しかしながら，巨視的にみれば，この平均運動は上 流側水路から放出された流れがはく離領域から流体を連 行しつつ徐々にその幅を増し, やがて下流側水路側壁に 達するものであることがわかっている。しかも，流れの 一部は逆流となってはく離領域に補給され，他の部分は 流下方向の流れとなってほぼ一様な流速分布を持った状 態に達する。このような流れの状態を考虑して急拡部に おける流速分布の特性を検討するには，（i 流速分布 の形状, (ii) 中心線流速の低減特性, (iii) はく離領域 の形状と長さ, (iv) はく離領域内の流れの状態などを 明らかにしなければならない。しかしながら，急桩部に おける流れの遷移は常流遷移・不安定遷移および射流遷 移に大別され，それぞれの流速分布特性は非常に異なっ ている。不安定遷移および射流遷移では現象が不安定か つ急激であるため, 流速分布の特性を検討することは非 常に困難である。したがってここでは現象が比較的安定 した常流遷移に着目し, その流速分布特性を吟味するに とどめる。

\section{（2）噴流理論適用の可能性}

常流遷移における急拡部近傍の流れに関する問題は, 幅の広、下流側水路に放出された流れの, 側壁よりの拘 束がある場における拡散とその下流側水路における変化 というものに帰せられよう。もちろん開水路急拡部を通 過する流れでは，その特異性が種々な形であらわれる が，急拡部の流速分布形や中心線流速の低減特性は，2 次元噴流のそれとかなり類似していることが実験的に明 らかにされている。このような観点から，噴流理論適用 の可能性を明らかにするため, つぎに示す事項について 詳細な実験的検討を行なった。もちろん境界条件につい ては異なるところがあることはいうまでもない。

(i) 急拡部における流速の水深方向分布

(ii) 接近流に対する急拡部の影響

(iii) 噴流の領域区分

流速の水深方向分布は, 水深 $h$ と水路幅 $B$ との比に よって異なるが, $h / B$ が小さくなるにつれて一様になる という事実が従来の実験 ${ }^{4}$ から指摘されている。図一13 は本実験 $\left(0.13<h / B_{2}<0.25\right)$ の一例であるが，すべ ての実験結果からも図一13 とほぼ同様 な分布が得られ ることがわかっている。ここに $u_{\max }$ : 最大平均流速, $B_{2}$ : 下流側水路の幅, $y$ : 幅方向座標である。したがっ て急拡部における流速分布は水樑方向に対し二次元的で あるとみなしうるものと思われる。図一14 は急拡断面 
图-13 Velocity distribution at the expansion:

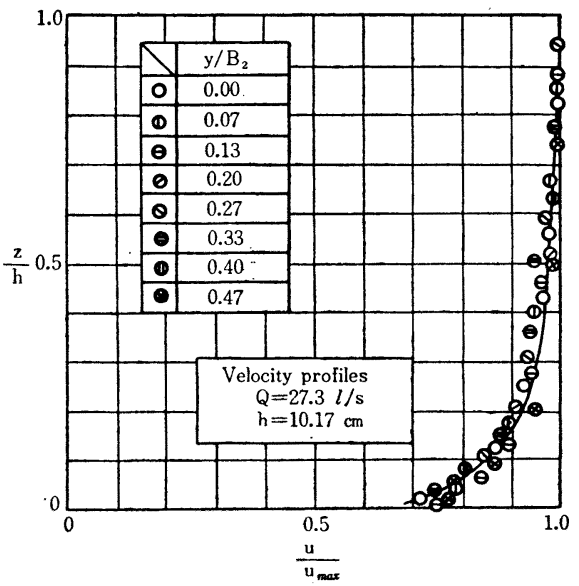

図-14 Velocity distribution of approaching.

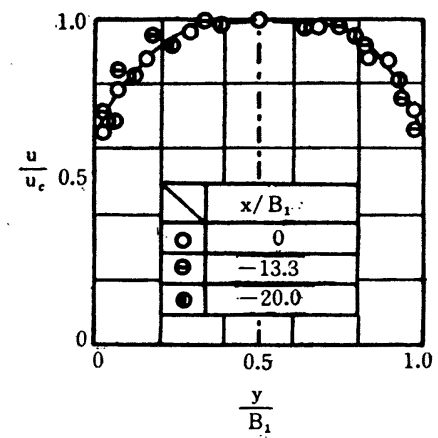

图-15 Characteristics of center velocity decay.

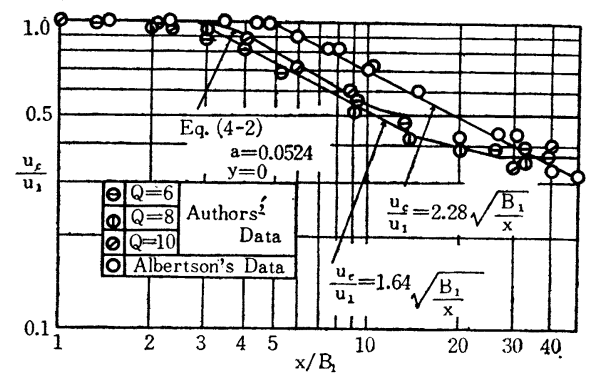

（噴出口）における流速分布を示すもので，上流側接近 流の流速分布をもって代表させ得ることがわかる。ただ し， $u_{c}$ は中心線流速を示し，この場合の実測值は，断 面平均流速に近いと考えられる水路底より $60 \%$ の水深 の流速を代表值として示した。図一15 は急拡部噴出口 から噴出した流れの中心線流速 $u_{c}$ の低減特性を示すむ ので, この図から流速分布が下流水路で一様になるまで の過程は 3 つに区分されることがわかる。すなわち,

(i) 噴出流速 $u_{1}$ が保持されるいわゆるZ Zone of flow establishment と呼ばれる領域

（ii）幅方向の拡散が卓越して行なわれるZ Zone of established flow と呼ばれる領域

（iii）下流水路側壁による拘束の効果が卓越し，次第
に下流側水路の流れとして確立されていく遷移領 域

なお, 図一15 には Albertson") の実験によって得られ た 2 次元理想噴流の流速低減特性が示されているが, 著 者らの実験值と比較すれば，低減特性はいずれも Toll$\operatorname{mien}^{10)}$ の低減公式

$$
\frac{u_{c}}{u_{1}}=K_{0}\left(\frac{B_{1}}{x}\right)^{1 / 2}
$$

を満足しており，急拡部における流れの流速低減特性は 2 次元理想噴流と同様に, 自由乱れによる混合の卓越す る領域が存在することを表わしている。ここに， $u_{1}$ ：噴 出口の流速, $K_{0}$ : 定数, $B_{1}$ : 噴出幅, $x$ : 流下距離に 沿った噴出口よりの距離である。 $K_{0}$ は Zone of flow establishment の長さを左右する実験定数で, Albert $\operatorname{son}^{9)}$ は 2 次元噴流で 2.28 , 岩崎・千秋 ${ }^{14)}$ は 3 次元噴 流で 2.20 を与えている。しかし, 噴出口の幅および接 近流の流速によってそれぞれ異なった值を示すもので， この実験では, 開水路急拡部において 1.64 が得られた。 また 図一15 には急拡部下流の流れを Mass flux の拡散 現象と考え, 境界条件として側壁における完全反射を仮 定して得られた式 (4-2) の計算結果が示されている。

$$
\begin{aligned}
\frac{u(x, y)}{u_{1}}= & \frac{1}{2} \sum_{n=-\infty}^{\infty}\left\{\operatorname{erf}\left(\frac{y-n B_{2}+\frac{B_{1}}{2}}{2 a x}\right)\right. \\
& \left.+\operatorname{erf}\left(\frac{\frac{B_{1}}{2}-y+n B_{2}}{2 a x}\right)\right\},(n= \pm 1, \pm 2, \cdots)
\end{aligned}
$$

ここに， $x, y$ : 流下方向および幅方向の座標, $B_{1}, B_{2}$ : 上下流水路の水路幅, $a:$ 定数

である。

以上の結果を比較することによって，急拡部の流れを 拘束された流れの場へ拡散される一つの噴流現象と考え る立場がほぼ妥当であると結論されよう。もちろん,この 他に流速分布の self-preservation に対する検討も行な われなければならないが,これについては後節に述べる。

\section{（3）境界条件の選択に関する検討}

急拡部の水理学的性状は, はく離領域の形成と噴流の 拡散過程によって代表されるといえる。2 次元理想噴流 では，噴流によって連行される流体の補給は 図一16の ように拘束なく行 なわれる。ところ が本実験の場合に は, 下流側水路側 壁のため幅方向の 流れは拘束され， 噴流によって連行 される流体は逆流 によって補給され

図-16 Jet boundary and co-ordinate system

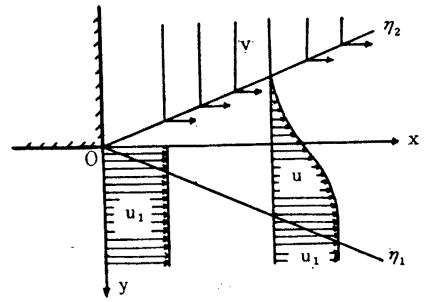


ねばならず，噴流と側壁との間に逆流領域 が 形成され る。

しかしながら, 逆流領域内の流速分布は不安定で, こ れを測定することは非常に困難であるから，実際現象を 説明するためには何らかのモデルを作る必要があり，し かも 2 次元噴流に関する Tollmien の理論から明らかな ように, 解を決定する境界条件を与えられた問題の特殊 性と関連せしめて十分妥当に選ぶことが，モデル化の基 本的要件である。しかしはく離領域内の流速分布の実相 は複雑で明らかではなく, 実験的事実にもとづく何らか の関係を必要とする。そこで, はく離領域内に一定流速 の逆流をもつ新し、領域(以下これを等逆流領域と呼ぶ） を考えた流れモデルを作ってみよう。表一4 は従来の研 究に用いられた境界条件と著者らのそれとを一括表示し たものである。

\section{表-4}

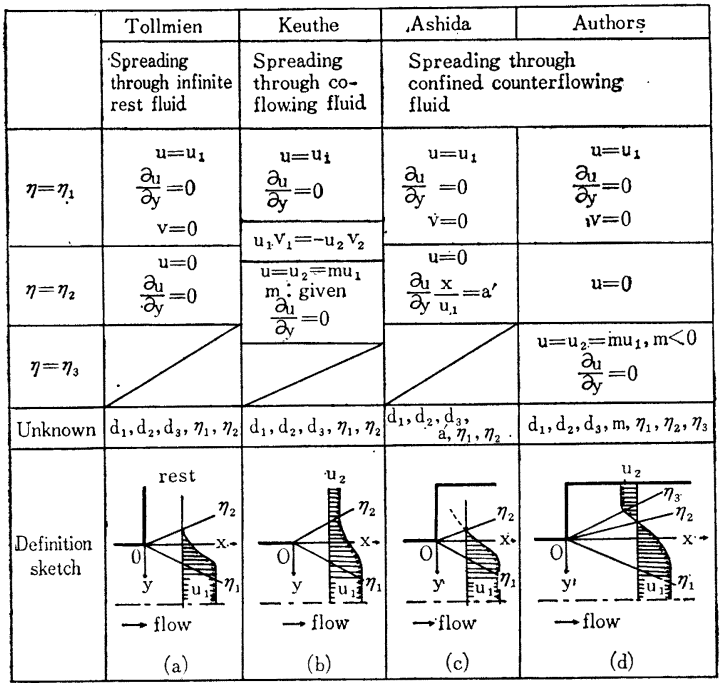

\section{（4）流速分布の計算法}

表一4 (d) のようなモデルにおける流速分布の計算に 当っては 7 つの未知数が含まれているが，境界条件は 6 つである。したがって残りの条件としては，各断面にお ける運動量保存の関係を用いる必要がある。周知の噴流 拡散の式より

$$
\begin{aligned}
& u=u_{1} F^{\prime}\left(\eta^{\prime}\right) \\
& F\left(\eta^{\prime}\right)=d_{1} e^{-\eta^{\prime}}+e^{(1 / 2) \eta^{\prime}}\left\{d_{2} \cos \frac{\sqrt{3}}{2} \eta^{\prime}+d_{3} \sin \frac{\sqrt{3}}{2} \eta^{\prime}\right\} \\
& \eta^{\prime}=\frac{1}{\left(2 c^{2}\right)^{1 / 3}}\left(\eta-\eta_{1}\right) \\
& \text { ここに, } u_{1} \text { : 噴出口における流速 } \\
& d_{1}, d_{2}, d_{3}: \text { 積分定数 } \\
& c: \text { 混合距離に関する定数 } \\
& \eta: y / x
\end{aligned}
$$

として, 表一4 (d) の境界条件は次のように表わされる。

$$
\begin{aligned}
& \eta^{\prime}=0 \text { において } \\
& F^{\prime}(0)=1 \quad \cdots \cdots \cdots \cdots \cdots \cdots \cdots \cdots \cdots \cdots \cdots \cdots \cdots \cdots \cdots \cdots \cdots \cdots \cdots \cdots \cdots \\
& F^{\prime \prime}(0)=0 \\
& \left\{\frac{\eta_{1}}{\left(2 c^{2}\right)^{1 / 3}} F^{\prime}(0)-F(0)\right\}=0 \\
& \eta^{\prime}=\eta_{2}^{\prime}=\frac{1}{\left(2 c^{2}\right)^{1 / 3}}\left(\eta_{2}-\eta_{1}\right) \text { において } \\
& F^{\prime}\left(\eta_{2}{ }^{\prime}\right)=0 \\
& \eta^{\prime}=\eta_{3}{ }^{\prime}=\frac{1}{\left(2 c^{2}\right)^{1 / 3}}\left(\eta_{3}-\eta_{1}\right) \text { において } \\
& \left\{\begin{array}{l}
F^{\prime}\left(\eta_{3}{ }^{\prime}\right)=m \\
F^{\prime \prime}\left(\eta_{3}{ }^{\prime}\right)=0
\end{array}\right.
\end{aligned}
$$

したがって積分定数 $d_{1}, d_{2}, d_{3}$ および流速比 $m$ はつぎ のようになる。

$$
\begin{aligned}
& d_{1}=\frac{1}{2}\left(d_{2}-1\right) \\
& d_{2}=\frac{1-e^{(3 / 2) \eta_{3}{ }^{\prime}}\left\{\cos \frac{\sqrt{3}}{2} \eta_{3}{ }^{\prime}-\frac{1}{\sqrt{3}} \sin \frac{\sqrt{3}}{2} \eta_{3}{ }^{\prime}\right\}}{1-e^{(3 / 2) \eta_{3}}\left\{\cos \frac{\sqrt{3}}{2} \eta_{3}{ }^{\prime}+\sqrt{3} \sin \frac{\sqrt{3}}{2} \eta_{3}{ }^{\prime}\right\}} \\
& d_{3}=\frac{1}{\sqrt{3}} \\
& m=-d_{1} e^{-\eta_{3}{ }^{\prime}}+\frac{1}{2} e^{(1 / 2) \eta_{3}{ }^{\prime}} \\
& \times\left\{d_{2}\left(\cos \frac{\sqrt{3}}{2} \eta_{3}{ }^{\prime}-\sqrt{3} \sin \frac{\sqrt{3}}{2} \eta_{3}{ }^{\prime}\right)\right. \\
& \left.+d_{3}\left(\sin \frac{\sqrt{3}}{2} \eta_{3}{ }^{\prime}+\sqrt{3} \cos \frac{\sqrt{3}}{2} \eta_{3}{ }^{\prime}\right)\right\}
\end{aligned}
$$

また $\eta_{1}, \eta_{2}{ }^{\prime}$ については，

$$
\begin{aligned}
& \frac{1}{\left(2 c^{2}\right)^{1 / 3}} \eta_{1}=d_{1}+d_{2} \cdots \cdots \cdots \cdots \cdots \cdots \cdots \cdots \cdots \cdots \cdots \cdots \cdots \\
& -d_{1} e^{-\eta_{2}{ }^{\prime}}+\frac{1}{2} e^{(1 / 2) \eta_{2}{ }^{\prime}} \\
& \quad \times\left\{d_{2}\left(\cos \frac{\sqrt{3}}{2} \eta_{2}{ }^{\prime}-\sqrt{3} \sin \frac{\sqrt{3}}{2} \eta_{2}{ }^{\prime}\right)\right. \\
& \left.\quad+d_{3}\left(\sin \frac{\sqrt{3}}{2} \eta_{2}{ }^{\prime}+\sqrt{3} \cos \frac{\sqrt{3}}{2} \eta_{2}{ }^{\prime}\right)\right\}=0
\end{aligned}
$$

が得られる。

第 7 番目の条件としては運動量保存の関係を用いる。 急抎部近傍の流れに直角な任意の断面における運動量 は, 常流遷移では水深の変化が微小であると仮定して計 算し，噴出口の運動量と等しいとおくと，

$$
\begin{aligned}
& u_{1}^{2}\left(\frac{1}{2} B_{1}-y_{1}\right)+\int_{y_{2}}^{y_{1}} u^{2} d y \\
& -\int_{y_{3}}^{y_{2}} u^{2} d y-\left(\Delta B+y_{3}\right) u_{2}^{2}=\frac{1}{2} B_{1} u_{1}^{2} \cdots
\end{aligned}
$$

が得られる。これを変数変換すると，

$$
\begin{aligned}
& \left(d_{1}+d_{2}\right)+\int_{0}^{\eta_{2}{ }^{\prime}}\left\{F^{\prime}\left(\eta^{\prime}\right)\right\}^{2} d \eta^{\prime}+\int_{r_{3}{ }^{\prime}}^{r_{r^{\prime}}{ }^{\prime}}\left\{F^{\prime}\left(\eta^{\prime}\right)\right\}^{2} d \eta^{\prime} \\
& +m^{2}\left\{\frac{1}{\left(2 c^{2}\right)^{1 / 3}} \frac{\Delta B}{x}+r_{3}{ }^{\prime}+\left(d_{1}+d_{2}\right)\right\}=0
\end{aligned}
$$


表-5

\begin{tabular}{c|c|c|c|c|c|c|c}
\hline$m$ & $d_{1}$ & $d_{2}$ & $d_{3}$ & $\eta_{2^{\prime}}$ & $\eta_{3}{ }^{\prime}$ & \multicolumn{2}{|c}{$\eta_{1} /\left(2 c^{2}\right)^{1 / 3}$} \\
\cline { 5 - 8 } & & & & & & $v_{1}=0$ & $u_{1} v_{1}=u_{2} v_{2}$ \\
\hline 0 & -0.0061 & 0.988 & 0.577 & -3.020 & -3.020 & 0.982 & 0.982 \\
-0.02 & -0.0057 & 0.990 & 0.577 & -2.865 & -3.074 & 0.984 & 1.060 \\
-0.04 & -0.0044 & 0.991 & 0.577 & -2.685 & -3.126 & 0.987 & 1.147 \\
-0.06 & -0.0036 & 0.993 & 0.577 & -2.605 & -3.184 & 0.989 & 1.235 \\
-0.08 & -0.0028 & 0.994 & 0.577 & -2.550 & -3.250 & 0.992 & 1.335 \\
-0.10 & -0.0021 & 0.996 & 0.577 & -2.500 & -3.324 & 0.994 & 1.444 \\
-0.12 & -0.0013 & 0.997 & 0.577 & -2.460 & -3.407 & 0.996 & 1.556 \\
-0.14 & -0.0006 & 0.999 & 0.577 & -2.430 & -3.502 & 0.998 & 1.698 \\
-0.16 & -0.0001 & 1.000 & 0.577 & -2.405 & -3.612 & 1.000 & 1.846 \\
-0.18 & -0.0004 & 1.001 & 0.577 & -2.390 & -3.745 & 1.001 & 2.015 \\
-0.20 & -0.0009 & 1.002 & 0.577 & -2.375 & -3.952 & 1.003 & 2.225 \\
\hline
\end{tabular}

图-18 Velocity distribution obtained through the analysis.

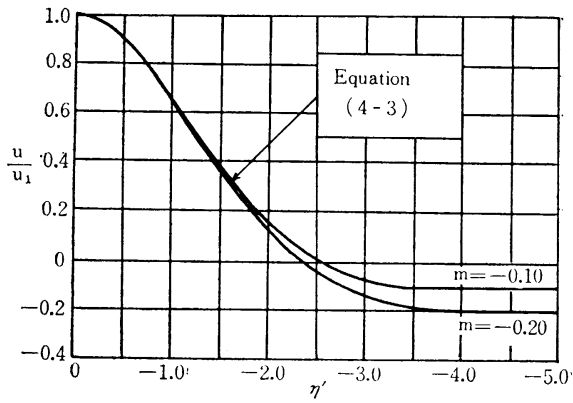

となる。 $x, \triangle B$ は与えられ， $d_{1}, d_{2}$ は $\eta_{3}^{\prime}$ の 関数であるか ら, 式 (4-19) は $\eta_{1}, \eta_{2}{ }^{\prime}, \eta_{3}{ }^{\prime}$ お よび $m$ の関数 となる。したが って式 (4-15), (4-16), (4-17) および (4-19) から $\eta_{1}, \eta_{2}{ }^{\prime}, \eta_{3}{ }^{\prime}$, 图-17 Boundary of the regions as function of $m$.

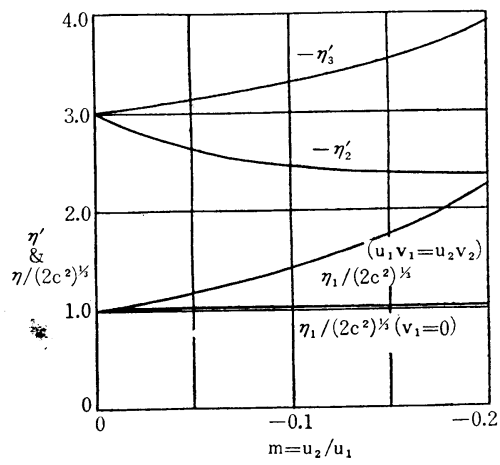

$m$ を求めるこ

とができる。この連立方程式の計算は非常に繁雑である が， $u_{2} / u_{1}=m(<0)$ の值は大きく変化をせず，実験に よるとせいぜい $0>m>-0.2$ の範囲であるから，各 種の $m$ について $\eta_{1}, \eta_{2}{ }^{\prime}, \eta_{3}{ }^{\prime}$ を容易に計算することがで きる。表一5および 図一17 は $m$ の代表值に対する $\eta_{1}$, $r_{2}{ }^{\prime}, \eta_{3}{ }^{\prime}$ を計算したもので, 図中 $u_{1} v_{1}=u_{2} v_{2}$ とあるのは, 式 (4-8) の境界条件の代りに, Keuthe ${ }^{11)}$ と同様な条件 （表一4 (b) 参照）から $\eta_{1}$ を計算したものである。

cの值はいまだ理論的に決定することが困難で, 従来 より多くの実験が行なわれ，Förthmann ${ }^{12)}: 0.0165$, 伎 藤 - 細井 ${ }^{13)}: 0.0197$, Tollmien : 0.0174, 岩崎 -千 秋 $^{14)}: 0.0129$ ０.0180 という結果が与えられている。 したがって平均值として適当な $c$ を採用すれば, 流速分 布を必要とする断面の位置 $x / \Delta B$ が与えられると, 式 (4-15)，(4-16)，(4-17) および式 (4-19) を満足する $m, \eta_{1} /\left(2 c^{2}\right)^{1 / 3}, \eta_{2} /\left(2 c^{2}\right)^{1 / 3}, \eta_{3} /\left(2 c^{2}\right)^{1 / 3}$ の值が求められ, 流速分布が得られる。図一18 はこれらの計算によって 得られた流速分布の一例を示したものである。以上の計 算は等逆流領域の仮定と自由乱れ，および流速分布の self-preservation の仮定の下で成り立つものであり，流 下距離が大きくなり, 逆流をともなっていても等逆流領 域自体が存在しない領域では, 表一4（d）に示した境界 条件と異なったそれぞれの条件のもとで解かなけれなら ないことは明らかである。

\section{5. はく離領域の性状}

\section{（1） 概 説}

4. においては表一4（d）に示したモデルに対し流速 分布を計算する一つの方法を示した。しかし前述の方法 は繁雑で多量の計算を必要とするばかりでなく，工学的 見地から開水路急拡部における水理学的特性を検討する 場合，流速分布よりもむしろ，はく離領域の形状・大き さあるいは一様な流速分布に回復するまでの流下距離な. どが重要な問題となる。また, 流速分布の計算には多く の方法がある が, 図一19に 示したようにい ずれの方法も実 测による誤差に 比較して大差が ない。したがっ てここでは実用 上の見地から， はく離領域の形 状・長さについ て考察する。 图-19 Velocity distribution in the
mixing region.

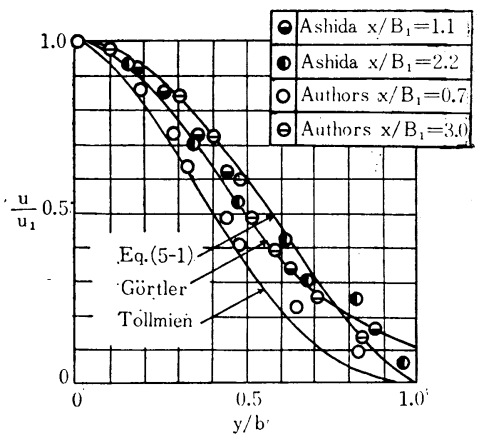

いま，流速分布として， Schlichting ${ }^{15)}$ の式 :

$$
\begin{aligned}
& \frac{u_{1}-u}{u_{1}-u_{2}}=f(\eta)=\left(1-\eta^{3 / 2}\right)^{2} \\
& \eta=\frac{y-y_{3}}{y_{1}-y_{3}}=\frac{y-y_{3}}{b} \cdots \cdots . . .
\end{aligned}
$$

を用いることにする。ここに， $y_{1}, y_{3}$ は混合距離端部の 幅方向座標で, $y=y_{1}$ で $u=u_{1}, y=y_{3}$ で $u=u_{2}<0$ を 満足している（表一4(d) 参照)。したがって $y_{1}-y_{3}=b$ は混合領域の幅を与える。 $b$ は乱れの特性によって決ま るものであるが, 自由乱れの場においては, 流下方向に 対しほぼ直線的に増大寸るものと考えられ, 式 (5-3)の ように表わされる。

$$
b=\frac{1}{\sigma} x
$$

ここに, $x$ : 流下距離, $\sigma$ : 定数である。のの值が大きけ れば大きいほど混合領域の幅は小となり，。㢬散の拘 
束の程度を表わす一つの指標となるから, 以下これを拘 束係数 (confine parameter) と呼ぶことにする。なお式 （5-1）の適用性については，Förthmann や Albertson の実験によって, 非常によい近似であることが明らかに されている。

\section{（2）流れのモデル化}

ここでは 表一4 (d) に示した流れパターンをさらに詳 細に説明し, 従来から拡散域・渦動域・逆流域あるいは はく離域など個々別々に用いられていた領域区分を統一 し, 急拡部下流の流れをモデル化した場合の解析的取り 扱いの可能性と限界とを検討する。図一20 ははく離領 域の長さが Potential core の長さより小さい場合にお ける急拡部下流の流れパターンモデルを示したものであ って，水路中心線と $y_{1}$ 座標との間の速度勾配のない Potential core, $y_{1}$ 座標と $y_{3}$ 座標との間の混合領域, 流速 0 の点を連ねた線の外側のはく離領域, 流れ方向の 質量が保存される $y_{4}$ 座標と水路側壁との間の渦動領域 および $y_{3}$ 座標と水路側壁との間の等逆流領域からなっ ている。このようなモデルに対する流速分布の計算は, すでに Abramovich ${ }^{16)}$ によって試みられているが，い まだ不完全である。著者らはこの方法を修正するととも に, 実験にもとづいて噴出口近傍のはく離領城の実用的 計算法について考察を行なった。なお，はく離領域の長 さが Potential core の長さより大きい場合には, 中心 線流速の低減を考慮した別の条件によるモデル化を必要 とすることはいうまでもない。

图-20 Symmetrical flow model assumed in the analysis.

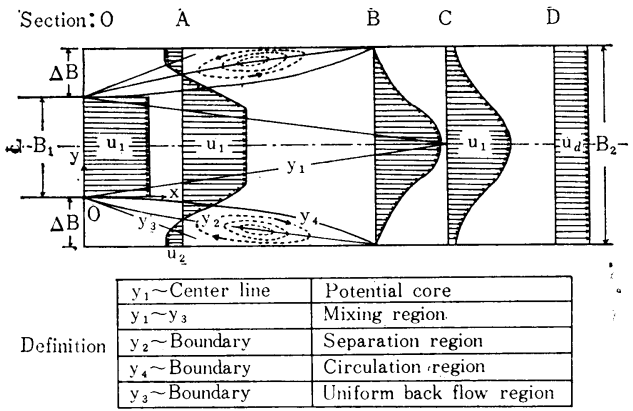

\section{（3）噴流拡大角}

上流側水路から噴出された流れが拡大していく角度 は，空気を用いた理想噴流のそれについて従来から多く の実験がなされ，とくに Tollmien は風洞実験によって 拡大角 $11^{\circ} 10^{\prime}$ を与えた。しかしながら, 開水路急拡部 におけるこれまでの実験では，拡大角はこの值より小さ く，したがってはく離領域の長さは非常に長くなること が指摘されている。図一20 において, 断面 0 と断面 $\mathrm{A}$ との間における運動量保存と連続の関係は, 圧力差を無 視すると，それぞれ

$$
\begin{aligned}
\frac{1}{2} B_{1} u_{1}{ }^{2}= & \left(\frac{1}{2} B_{1}-y_{1}\right) u_{1}{ }^{2}+\int_{y_{2}}^{y_{1}} u^{2} d y \\
& -\int_{y_{3}}^{y_{2}} u^{2} d y-u_{2}{ }^{2}\left(\Delta B+y_{3}\right) \quad \cdots \cdots(5-4) \\
\frac{1}{2} B_{1} u_{1}= & \left(\frac{1}{2} B_{1}-y_{1}\right) u_{1}+\int_{y_{3}}^{y_{1}} u d y+u_{2}\left(\Delta B+y_{3}\right)
\end{aligned}
$$

となる。つぎに渦動領域内の連続の条件から，

$$
\int_{y_{2}}^{y_{4}} u d y=-\int_{y_{3}}^{y_{2}} u d y-u_{2}\left(\Delta B+y_{3}\right)
$$

が得られる。

これらの式は式 (5-2) によって無次元化され, それぞ れつぎのようになる。

$$
\begin{aligned}
\frac{y_{1}}{b} \bar{b}= & \bar{b} \int_{\eta_{2}}^{1}\left(\frac{u}{u_{1}}\right)^{2} d \eta \\
& -\bar{b} \int_{0}^{\eta_{2}}\left(\frac{u}{u_{1}}\right)^{2} d \eta-m^{2}\left(1+\frac{y_{3}}{b} \bar{b}\right) \\
\frac{y_{1}}{b} \bar{b} & =\bar{b} \int_{0}^{1} \frac{u}{u_{1}} d \eta+m\left(1+\frac{y_{3}}{b} \bar{b}\right) \ldots \ldots \ldots \ldots \ldots \ldots \ldots \ldots \ldots \ldots \ldots . . .
\end{aligned}
$$

ここに,

$$
\begin{aligned}
& \frac{u_{2}}{u_{1}}=m, \quad(m<0) \\
& \frac{b}{\Delta B}=\bar{b} \\
& \eta_{i}=\frac{y_{i}-y_{3}}{b}, \quad(i=1,2,3,4)
\end{aligned}
$$

式 (5-7) と (5-8) とから $\bar{b}$ を消去すると，

$$
\frac{y_{1}}{b}=\frac{\int_{0}^{1}\left(\frac{u}{u_{1}}\right)^{2} d \eta+m \int_{0}^{1} \frac{u}{u_{1}} d \eta-2 \int_{0}^{\eta_{2}}\left(\frac{u}{u_{1}}\right)^{2} d \eta}{1+m}
$$

が得られる。流速分布式 (5-1) を用いて上式を積分する と,

$$
\begin{aligned}
\frac{y_{1}}{b}= & \frac{1}{1+m}\left\{0.416+0.718 m+0.766 m^{2}\right. \\
& \left.-2 \int_{0}^{\eta_{2}}\left(\frac{u}{u_{1}}\right)^{2} d \eta\right\} \cdots \cdots \cdots \cdots \cdots \cdots \cdots \cdots \cdots \cdots \cdots
\end{aligned}
$$

となる。また式 (5-2) より

$$
\frac{y_{3}}{b}=\frac{y_{1}}{b}-1
$$

である。式 (5-13)，(5-14) を式（5-8）に代大すると， $\bar{b}$ は式 (5-15) のようになる。

$$
\begin{aligned}
& \bar{b}=-m(1+m) /\left\{0.134-0.302 m+0.598 m^{2}\right. \\
& \left.+0.766 m^{3}+2(1-m) \int_{0}^{\eta_{2}}\left(\frac{u}{u_{1}}\right)^{2} d \eta\right\} \\
& =\phi\left(m, \eta_{2}\right)
\end{aligned}
$$

また, $y=y_{2}$ で $u=0$ であるから，

$$
\frac{1}{1-m}=\left(1-\eta_{2}{ }^{3 / 2}\right)^{2}
$$

が得られる。式 (5-3)，(5-11) および (5-15) から 


$$
\begin{aligned}
\frac{x}{\Delta B}= & -m \sigma(1+m) /\left\{0.134-0.302 m+0.598 m^{2}\right. \\
& \left.+0.766 \mathrm{~m}^{3}+2(1-m) \int_{0}^{n_{2}}\left(\frac{u}{u_{1}}\right)^{2} d \eta\right\} \cdots(5-17)
\end{aligned}
$$

が得られる。

$\sigma$ は実験的に決められており，Albertson ${ }^{9}$ : 2.00 2.50, Abramovich ${ }^{16)}: 3.33$, Tollmien ${ }^{10)}: 2.46$ を与 えている。これはもちろん自由乱れの場合の值であり， 開水路急桩部のように側壁の拘束がある場合には， $\sigma$ は 大きな值となることが予想される。しかし，。の值が与 えられると, 流下方向の任意断面 $x / \Delta B$ における $m$ と $\eta_{2}$ の值が式 (5-16), (5-17) から計算され, 式 (5-11), (5-12)，(5-13) および式 (5-14) から $y_{1}, y_{2}, y_{3}$ の座 標が求められる。図一21 はこの計算手順を図式化した ものであり，実験值もプロットされている。適当な $\sigma を$ 選ぶことによって, 流下距離 $x / \Delta B$ における逆流の平均 流速 $m u_{1}$ が得られ，同時に $y_{1} / \Delta B, y_{2} / \Delta B$ および $y_{3} /$ $\Delta B$ を求めることができる。図一21 の点線は，芦田博 士によって得られたはく離領域の形状に関する実験式 (5-18) を示すものである。

図-21 Relation between $x / \Delta B, \bar{b}, m$ and $y / \Delta B$.

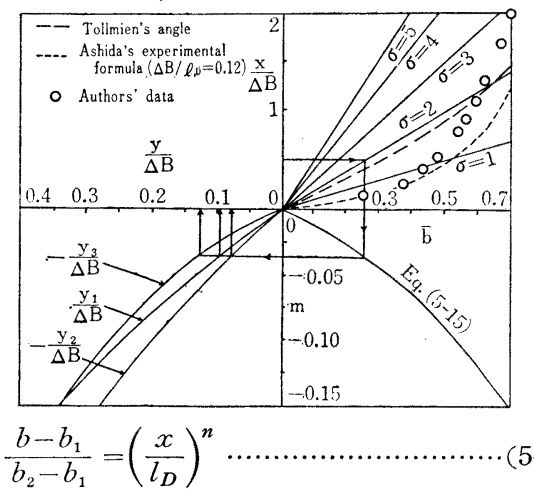

ここに, $b$ : 流下距離 $x$ における通水断面幅, $b_{1}, b_{2}$ : 上下流水路幅, $l_{D}$ : はく離領域の長さ, $n:$ 実験定数 $(n=0.6)$ である。図一21 からつぎのことが明らかにな る。すなわち，実験值を実験式 (5-18) および Tollmien の拡大角と比較すると, 噴出口のごく近傍では Tollmien の值より大きく流下距離の増大にともない逆に小 さくなって噴流の拡大がゆるやかになる。これは流下距 離の増大にともな って，側壁による 拘束の効果が現わ れるためと考えら れる。したがって 流下距離 $x$ が大き くなるにつれて， 拘束係数 $\sigma$ は大き くなる。実験より $\sigma$ の值は, 噴出口
近傍で $0.5, x / \Delta B=1$ 付近で $\sigma=2.0$ となる。

図一22 は $\sigma=2.0$ とおいて計算された噴出口近傍の流 れのはく離を示したものである。

\section{（4）はく離領域の長さ}

上に示した計算法は，等逆流領域の仮定が許される噴 出口のごく近傍におけるはく離領域に適用されるもの で，はく離領域全体の長さを推定することはできない。 現在のところ，これは理論的に評価されていないもの で，多くの実験より経験的に得られているにすぎない。 本節では流下距離が増大するにつれて拘束係数 $\sigma$ の值が 大きくなることから, はく離領域全体について平均化さ れた拘束係数 $\sigma_{m}$ を考え，これと以下に示す流れのモデ ルとを用いて，はく離領域の長さについて考察する。急 拡部における常流遷移流のパターンは, Potential core の長さ $l_{p}$ とはく離領域の長さ $l_{s}$ とによって, (i ) $l_{p}$ $>l_{s}$, (ii) $l_{p}=l_{s}$ および (iii) $l_{p}<l_{s}$ の 3 つの形式に 分類できる。一般に水路幅拡大比 $\beta_{*}$ が小さい拡大部で は $l_{p}>l_{s}$ と考えられ， $\beta_{*}$ が大きい場合には，これと 反対に $l_{p}<l_{s}$ と考えられる。図一23 はこれらの関係 を示した流れのモデルであり，つぎのような仮定にもと づいている。

図-23 Flour model assumed in the analysis.
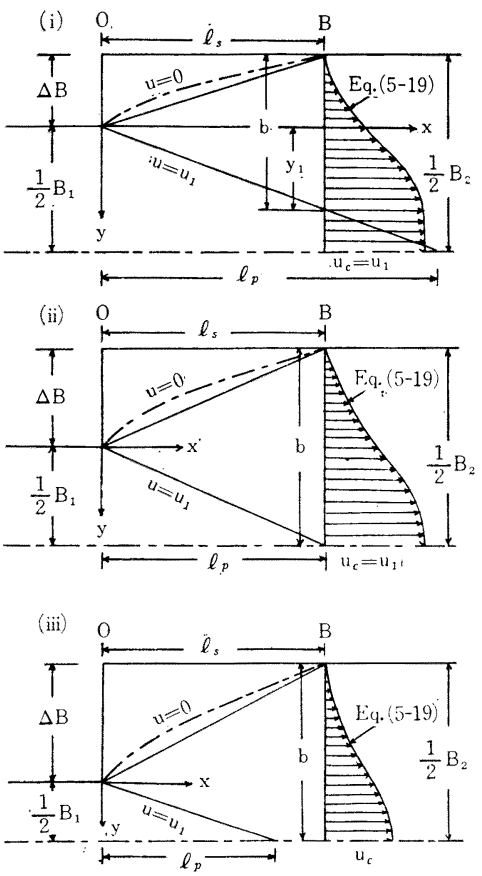

（a）常流遷移の流れでは水面勾配が小さく，二次元 的な取り扱いができる。

(b) 断面Bにおける混合領域の幅bはそれぞれ図に 示したようにとる。

（c）混合領域内の流速分布は, 式 (5-1), (5-2) か ら $u_{1}=u_{c}, u_{2}=0, y_{3}=-\Delta B$ とおいてつぎのよ 
うに与えられる。

$$
\begin{aligned}
& \frac{u_{c}-u}{u_{c}}=f(\eta)=\left(1-\eta^{3 / 2}\right)^{2} \\
& \eta=(y+\Delta B) / b \ldots \ldots \ldots \ldots \ldots . . .
\end{aligned}
$$

図一23 において, 断面 0 と断面 B との連続の関係を 求めると，それぞれつぎのようになる。

(i) $l_{p}>l_{s}$ の場合

$$
u_{1}\left(\frac{1}{2} B_{1}-y_{1}\right)+\int_{-\Delta B}^{y_{1}} u d y=\frac{1}{2} B_{1} u_{1} \cdots \cdots(5-2
$$

式 (5-19)，(5-20) を用いて変数変換すると式 (5-22) が 得られる。

$$
y_{1}=\frac{c_{2}}{1-c_{2}} \Delta B
$$

ただし，

$$
c_{2}=\int_{0}^{1}\left\{1-\left(1-\eta^{3 / 2}\right)^{2}\right\} d \eta_{i}=\text { const. }
$$

いま, 式 (5-20) において, はく離領域全長にわたる $\sigma$ の值を平均化して考え，これを $\sigma_{m}$ とすると，

$$
b=y_{1}+\Delta B=l_{s} / \sigma_{m}
$$

が得られる。したがって, $l_{s}$ と $\beta_{*}=B_{2} / B_{1}$ （水路幅拡大 比）との間にはつぎの関係が成り立つ。

$$
\frac{l_{s}}{B_{1}}=\frac{1}{2\left(1-c_{2}\right)} \sigma_{m}\left(\beta_{*}-1\right), \quad\left(\beta_{*}<\frac{1}{c_{2}}\right)
$$

(ii) $l_{p}=l_{s}$ の場合

この場合には式 (5-25) の関係が得られる。

$$
\beta_{*}=\frac{1}{c_{2}}
$$

これは $l_{p}$ と $l_{s}$ の大小関係が変わる限界の水路幅拡大 比を示すものである。

(iii) $l_{p}<l_{s}$ の場合

$$
\frac{1}{2} B_{2} u_{c} \int_{0}^{1}\left\{1-\left(1-\eta^{3 / 2}\right)^{2}\right\} d \eta=\frac{1}{2} B_{1} u_{1}
$$

から，式 (4-1) を用いてつぎの関係が得られる。

$$
\frac{l_{s}}{B_{1}}=\left(c_{2} K_{0} \beta_{*}\right)^{2} \quad\left(\beta_{*}>\frac{1}{c_{2}}\right)
$$

前にも述べたように, 式 (4-1) における $K_{0}$ の值は理 論的に求めることがいまだ困難であるが， $\beta_{*}=1 / c_{2}$ にお いて, 式 (5-24) と式 (5-26) は等しい值となるはずで あるから， $K_{0}$ は

$$
K_{0}=\sqrt{\frac{\sigma_{m}}{2 c_{2}}}
$$

となり, 式 (5-26) は $\sigma_{m}$ を用いて表わすとつぎのよう になる。

$$
\frac{l_{s}}{B_{1}}=\frac{1}{2} c_{2} \sigma_{m} \beta_{*}^{2}, \quad\left(\beta_{*}>\frac{1}{c_{2}}\right)
$$

式 (5-24)，(5-28）は常流遷移の Froude 数の範囲に おいて，急拡部に形成されるはく離領域の長さを表わす もので， $\sigma_{m}$ は実験によって求めなければならない。

図一24 は従来の実験值 ${ }^{4}$ をプロットしたものである が，理論值と比較することによってつぎのようなことが
明らかとなる。すなわ ち, $\beta_{*}$ が小さい範囲 では $l_{s}$ は $\beta_{*}$ に比例 し, $\beta_{*}$ が大きい場合 には $l_{s}$ は $\beta_{*}^{2}$ に比例 して増大する。またこ の場合, $\sigma_{m}$ の值はい ずれも 4.0 ６.0 (平均 5.0）の範囲にある。 なお，実験值がばらつ くのは測定誤差による ばかりでなく, Froude 数の変化を無視してい
図-24 Relation between $l_{s} / B_{1}$ and $\beta_{*}$.

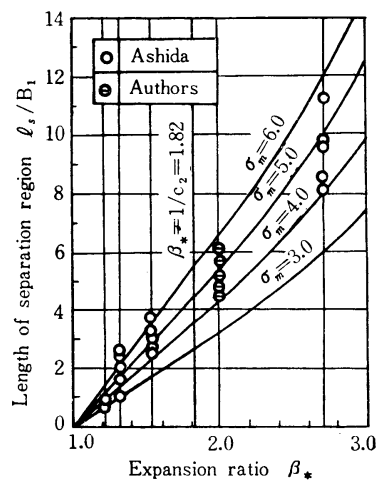
るためにおこるものと考えられ，実験から Froude 数が 大きいほど $l_{s} / B_{1}$ も増大寸ることが認められた。しかし ながら, 不安定なはく離領域の長さを測定する精度から 考えて, 式 (5-24), (5-28) はほぼ実測值を説明し得る と思われる。

\section{6. 急拡部における流れの非対称性}

実際には開水路急拡部の流れは, ほとんど対称な拡散 をせずに，下流側水路のいずれかの一方に偏する非対称 はく離領域を形成する。この事実は従来から多くの研究 者によって指摘されてきたが，ここでは実験にもとづく 簡単な非対称流れのモデルを仮定し, はく離領域の長さ に関する解析を試みよう。

\section{（1）非対称性の原因 (Coanda 効果)}

急拡部における流れの非対称性の原因として，まず第 一に傾斜・形状・粗度など水路自体の非対称性が考えら れる。しかしながら，片側のはく離領域に水を補給した り，あるいは板などによって強制的に流れを反対側に偏 向させると，流れがその状態のまま安定するという事実 は，上述の原因のみでは説明し得ない。

第二の原因として考えられるのは，逆流補給の非対称 性である。すなわち噴流が下流水路に放出されるとき流 体の連行現象を生ずるが, 連行量を補給するため下流水 路の両側に逆流が発生する。ところが, 水面変動や流速 分布などに微小な非対称性があると, 逆流による流体の 補給にも微量の差を生じ, その結果, 噴流を横切って圧 力差を生ずる。この圧力差によって, 噴流に若干のわん 曲が与えられ, わん曲した側のはく離領域に対する流体 の補給はさらに減少する。これはさらに噴流のわん曲を 増大させ，わん曲による遠心力と圧力差とが平衡する状 態までわん曲して安定を保つようになる。このように噴 流が固体壁面の近くでそれに引き寄せられわん曲する傾 向を示すことは, 通常よく観察される現象で, Coanda ${ }^{17)}$ がこの現象を内燃機関の排気能率の改善, 高推力ノズル の噴出能力増大, および翼の揚力係数増大などに利用し 
たことから，「Coanda 効果」と呼ばれている。

これら 2 つ主要な原因によって, 急拡部における噴 流は偏向すると考えられる。しかしながら,これら $2 つ$ の原因は互、に独立しているわけではなく, 逆流補給に 関する初期条件の非対称性は第一の原因によって影響を 受ける場合が多いと考えられるから，これら2つの原因 が有機的に作用して噴流の偏向を支配しているとみてよ w。

\section{（2）流れのモデル化}

急拡部における流れの本質的特性は, 噴流によるはく 離領域からの連行にあるといえる。噴流はわん曲して周 囲の流体を連行しつつ下流側水路側壁に衝突して 2 分さ れ,一部はふたたびはく離領域に逆流として返される。

いま, 安定状態では連行される流量と逆流として補給 される流量とが平均的にバランスしていると考えると，

Bourque $^{18)}$, Dodds ${ }^{19)}$, Sawyer ${ }^{20)}$ などの一連の実験に用 いられたものを修正して作った開水路急桩部の流れのモ デルが説明される（図一25 参照)。

图-25 Asymmetrical flow model assumed in the analysis.

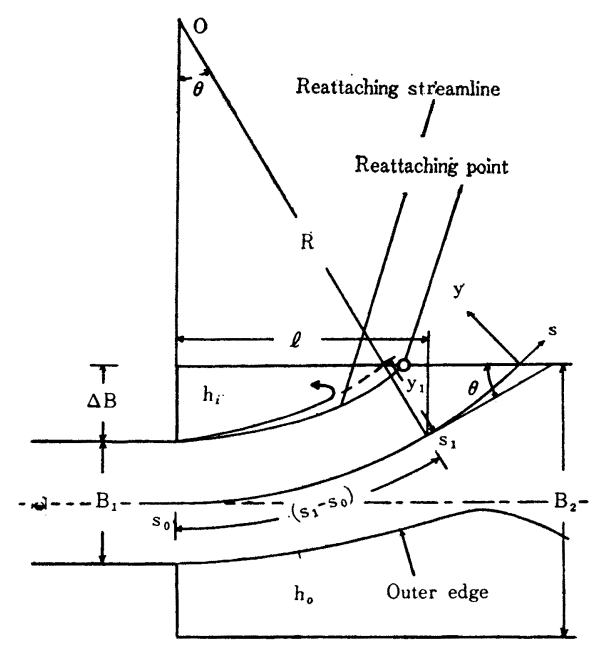

噴流の流速分布は 2 次元噴流のものと同様であると仮 定して,

$$
\frac{u_{m}-u}{u_{m}}=f(\eta)=\left(1-\eta^{3 / 2}\right)^{2}
$$

ただし

$$
\eta=\frac{b-y}{b}
$$

とし, 混合領域の幅 $b$ は式 (5-3) と同様に拘束係数 $\sigma$ を 用いて,

$$
b=\frac{1}{\sigma} s
$$

として与えられるとする。ここに, $u_{m}$ : 噴流中心線上に おける流速, $b$ : 混合領域の幅, $s$ : 噴流中心線に沿って とる流れ方向の座標である。
ただし，下流水路側壁の拘束効果のため， $\sigma$ は自由乱 れの場に対して与えられる值よりも大きい值をとるべき であり, また噴流がわん曲する場合, 混合領域の外縁と 内縁では，異なった $\sigma$ 值を示すことを注意しなければ ならない。すなわち, 噴流の内縁では流れのわん曲によ る遠心力のため, 乱れによる混合が抑制されて $\sigma$ は大き く, 外縁では逆に小さくなると考えられる。しかしなが ら，実際にはこの評価が困難であるから，解析にあたっ ては簡単のため, これを等しいとして一つの実験定数と 考えて取り扱わざるを得ない。

つぎに単位水深当りの噴流の運動量を $M$, 流量を $Q$ とすると，これらは式 (6-1)，(6-2) および (6-3)を用 いてつぎのように表わされる。

$$
\begin{aligned}
& M=2 \int_{0}^{b} \rho u^{2} d y=2 b \rho u_{m}^{2} \int_{0}^{1}\left\{1-\left(1-\eta^{3 / 2}\right)^{2}\right\}^{2} d \eta \\
& =2 c_{1} \rho u_{m}^{2} \frac{s}{\sigma}
\end{aligned}
$$

ただし，

$$
\begin{aligned}
c_{1} & =\int_{0}^{1}\left\{1-\left(1-\eta^{3 / 2}\right)^{2}\right\}^{2} d \eta=\text { const } \ldots \ldots \ldots . . \\
Q & =2 \int_{0}^{b} u d y=2 b u_{m} \int_{0}^{1}\left\{1-\left(1-\eta^{3 / 2}\right)^{2}\right\} d \eta \\
& =2 c_{2} u_{m} \frac{s}{\sigma} \ldots \ldots \ldots \ldots \ldots \ldots \ldots \ldots \ldots \ldots \ldots \ldots \ldots \ldots \ldots \ldots \ldots \ldots
\end{aligned}
$$

ただし，

$$
c_{2}=\int_{0}^{1}\left\{1-\left(1-\eta^{3 / 2}\right)^{2}\right\} d \eta=\text { const. }
$$

したがって，

$$
u_{m}=\sqrt{\frac{1}{2 c_{1}} \frac{M \sigma}{\rho s}}, \quad Q=\sqrt{\frac{2 c_{2}^{2}}{c_{1}} \frac{M s}{\sigma \rho}}
$$

図一25において, はく離領域内の水深を一定と仮定 して $h_{i}$ および $h_{0}$ とすると, 噴流を横切って働く圧力 差 $\triangle P$ は,

$$
\Delta P=\rho g\left(h_{0}-h_{i}\right)
$$

であり, また噴流に作用する圧力差と噴流のわん曲によ る遠心力とのつりあいの関係は，

$$
\Delta P=\int_{R_{1}}^{R_{2}} \frac{\rho u^{2}}{r} d r
$$

として与えられる。ここに，r: 咬流の任意点における 回転半径, $R_{1}, R_{2}$ : それぞれ噴流内縁と外縁における回 転半径である。 $R_{1}, R_{2}$ は $s$ の関数であり, $u$ は $s$ と $r$ との関数であるから, 式 (6-10) を積分することは困難 である。したがって, 噴流中心線を半径 $R$ の円弧と仮 定して, つりあいの関係をつぎのように近似する。

$$
\Delta P=\rho g\left(h_{0}-h_{i}\right)=\frac{M}{R}
$$

この関係は噴流の幅 $B_{1}$ が $R$ に比較して小さい場合, すなわち水路幅桩大比 $\beta$ * が大きい場合ほど良い近似を 与える。 


\section{（3）Reattachment とはく離領域の長さ}

図一25 に示した流れのモデルを用いて，はく離領域 の長さを解析するにあたって, 側壁に衝突する噴流のも つ運動量の配分に関係する $s$ 座標の值 $s_{1}$ がどれほどで あるかを考えなければならない。 $s_{1}$ 断面では流速分布や 流向に対し Reattaching の影響がないという条件を満足 していなければならないが，Sawyer ${ }^{20)}$ と同様に便宜的 に $u / u_{m}=0.1$ の流線が下流水路側壁と交差する断面と すると, 式 (6-1) に $u / u_{m}=0.1$ を代入して,

$$
\frac{y_{1}}{s_{1}}=\frac{1}{\sigma} c_{3}
$$

が得られる。ここに, $y_{1}: s_{1}$ 断面における噴流の半幅, $c_{3}:$ 定数である。

つぎに， $s$ 座標は急拡断面を原点としているのではな く, 噴流が点源から拡散すると考えるいわゆる噴流理論 の仮想点源に原点をとっているから，噴出口の $s$ 座標を $s_{0}$ であらわすと, $s_{0}$ 断面では一様な流速分布を考えてい るから，式 (6-8) を用いて，

したがって，

$$
\sqrt{M B_{1} \rho}=\rho \sqrt{\frac{2 c_{2}{ }^{2}}{c_{1}} \frac{M s_{0}}{\sigma \rho}}
$$

$$
s_{0}=c_{4} B_{1} \sigma \text {, ただし } c_{4}=c_{1} / 2 c_{2}^{2} \text {. }
$$

となる。この $s_{0}$ は急拡断面の $s$ 座標であるから, 幾何 的条件はつぎのように表わされる。

$$
\begin{aligned}
& s_{1}-s_{0}=R \theta \\
& l=R \sin \theta \\
& \frac{1}{2} B_{1}+\Delta B=R(1-\cos \theta)+y_{1} \cos \theta
\end{aligned}
$$

また噴流中心線と Reattaching streamline との間の 単位時間当りの流れの質量は一定であって, 急拡部から 放出される質量の半分に等しくなければならないから， つぎの関係が得られる。

$$
\begin{aligned}
\frac{1}{2} \sqrt{M B_{1} \rho}= & \rho \int_{0}^{y_{R}} u d y=\sqrt{\frac{1}{2 c_{1}} \frac{M s \rho}{\sigma}} \\
& \times \int_{\eta_{R}}^{1}\left\{1-\left(1-\eta^{3 / 2}\right)^{2}\right\} d \eta \\
= & T \sqrt{\frac{1}{2 c_{1}} \frac{M s \rho}{\sigma}} \cdots \cdots \cdots \cdots . .
\end{aligned}
$$

ここに, $T=\int_{\eta_{R}}^{1}\left\{1-\left(1-\eta^{3 / 2}\right)^{2}\right\} d \eta, \eta_{R}=1-\sigma \frac{y_{R}}{s}$, $y_{R}$ : 噴流中心線と Reattaching streamline との閒の幅 である。

$$
\text { 式 (6-17) から }
$$

$$
\frac{1}{T^{2}}=\frac{2}{c_{1}} \frac{s}{B_{1} \sigma}
$$

となるが, 上式で $s=s_{1}$ における $T$ を $T_{1}$ とし, 式 （6-13）を代入すると，

$$
T_{1}^{2}=c_{2}^{2} \frac{s_{0}}{s}
$$

を得る。式 (6-12) (6-19) を用いると, 水路幅拡大比 $\beta_{*}$, はく離領域の長さ $l$ および噴流を横切る圧力差をつ
ぎのように無次元量で表わすことができる。すなわち，

$$
\begin{aligned}
\frac{\Delta B}{B_{1}}= & \frac{1}{2}\left\{\frac{c_{1} \sigma}{\theta}\left(\frac{1}{T_{1}{ }^{2}}-\frac{1}{c_{2}{ }^{2}}\right)(1-\cos \theta)\right. \\
& \left.+c_{1} c_{3} \frac{\cos \theta}{T_{1}{ }^{2}}-1\right\} \ldots \ldots \ldots \ldots \ldots \ldots \ldots \ldots \ldots \ldots \ldots \ldots \ldots \ldots \ldots \ldots \\
\frac{l}{\Delta B}= & \frac{c_{1} \sigma\left(\frac{1}{T_{1}{ }^{2}}-\frac{1}{c_{2}{ }^{2}}\right) \frac{\sin \theta}{\theta}}{\left\{\frac{c_{1} \sigma}{\theta}\left(\frac{1}{T_{1}{ }^{2}}-\frac{1}{c_{2}{ }^{2}}\right)(1-\cos \theta)+c_{1} c_{3} \frac{\cos \theta}{T_{1}{ }^{2}}-1\right\}}
\end{aligned}
$$

$$
\frac{h_{0}-h_{i}}{\frac{u_{1}{ }^{2}}{2 g}}=\frac{4 \theta}{c_{1} \sigma\left(\frac{1}{T_{1}{ }^{2}}-\frac{1}{c_{2}{ }^{2}}\right)}
$$

ここに， $u_{1}$ は噴出口における流速である。

つぎに, Reattaching point における連続の条件と運 動量のバランスを考えることによって, $T_{1}$ と $\theta$ との関 係が得られる。ただし，ここでは Bourque ${ }^{18)}$ が示した Görtler type ${ }^{21)}$ の流速分布によらず, 式 (6-1) の流速 分布を用い, かつ衝突後の流速分布を仮定したDodds ${ }^{19)}$ の方法によることにする。すなわち, Reattaching point において衝突した噴流は 二分され，一部は逆流と なり，他の一部は流下方 向の流れとなるが，これ らの流れを 図一26 に示 すように，最大流速をそ れぞれ $u_{m 1} \phi(\theta)$ と $u_{m 1}$ とし, 式 (6-1) の流速分 布の半分を持ったものと 考える。ここに, $\phi(\theta)$ は
図-26 Velocity distribution assumed in the analysis.
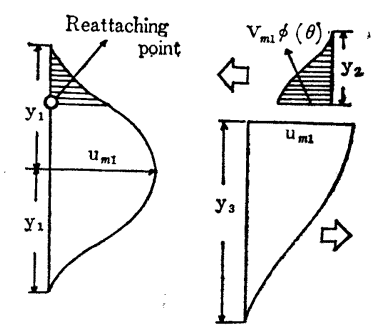
$\theta=0$ で $\phi(0)=0, \quad \theta=$ $\pi / 2$ で $\phi(\pi / 2)=1$ であるような任意の関数であるが，こ の場合簡単に $\phi(\theta)$ として $\sin \theta$ を用いることにする。 図において $u_{m 1}$ は $s=s_{1}$ における噴流の最大流速であ り， $y_{2}, y_{3}$ はそれぞれ逆流と流下方向の流れの幅であ る。

Reattaching point における連続の条件から，

$$
2 y_{1}=y_{2} \sin \theta+y_{3}
$$

となり, 流下方向の運動量のバランスを考えると，

$$
2 y_{1} \cos \theta=-y_{2} \sin ^{2} \theta+y_{3}
$$

となるから，つぎの関係が得られる。

$$
\frac{y_{2}}{2 y_{1}}=\frac{1}{\sin \theta}\left(\frac{1-\cos \theta}{1+\sin \theta}\right)
$$

さて, 逆流の流量 $Q_{b}$ は式 (6-6)，(6-12) および (6-25) を用いて,

$$
Q_{b}=2 y_{1} \frac{c_{2}}{c_{3}} \sqrt{\frac{1}{2 c_{1}} \frac{M \sigma}{\rho s_{1}}}\left(\frac{1-\cos \theta}{1+\sin \theta}\right) \cdots
$$

となり，また式（6-8）および (6-12) から,

$$
\frac{1}{2}\left(Q_{1}-Q_{0}\right)=c_{2} \sqrt{\frac{1}{2 c_{1}} \frac{M s_{1}}{\sigma \rho}}\left(1-\sqrt{\frac{s_{0}}{s_{1}}}\right)
$$


となる。ここに， $Q_{0}, Q_{1}$ はそれぞれ $s_{0}, s_{1}$ 断面におけ る流下方向の流量である。

式 (6-26) と式 (6-27) とは等しい值となるはずであ るから，式 (6-19) を用いて結局つぎのようになる。

$$
T_{1}=c_{2}\left\{1-2\left(\frac{1-\cos \theta}{1+\sin \theta}\right)\right\}
$$

このようにして得られた式(6-28)を式 (6-20), (6-21) および式 (6-22) に代入すると, 水路幅拡大比と衝突角 との関係, 水路幅拡大比 とはく離領域の長さとの 图一27 Relation between $\theta$ and $\beta_{*}$.

関係を求めることができ る。図-27 は式 (6-20) と式 (6-28) とによって 得られた $\beta_{*}$ と $\theta$ との関 係を示したもので, 拘束 係数 $の$ の值を与えると， 衝突角 $\theta$ を求めることが できる。

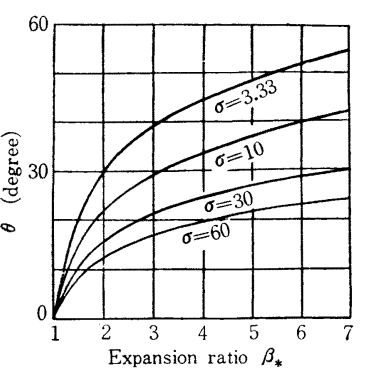

\section{(4) 実験結果टその考察}

実験は搪大比 $\beta_{*}=2$ の急扡部に対して行なった。は く離領域の形状はピトー管による流速測定と写真撮影と によって測定された。この場合, tracerとしては, キシ レン, 四鉛化炭素, 酸化鉛, アルコールおよびアルミ粉 の混合液を用いたが 写真一1 はその一例を示すむのであ る。

図一28 はピトー管によって測定した混合領域内の流 速分布の一例であるが， $x=10 \mathrm{~cm}$ における值は Zone of flow establishment 内における流速分布を代表する ものである。

$x=45 \mathrm{~cm}$ における值は Potential core の消滅した断 面の流速分布を代表し, 図一25 の $s_{1}$ 断面の流速分布に ほぼ対応するものである。これらの結果から, Reattaching するまでの流速分布の Self-preservation と2 次 元噴流の流速分布に対する式 (6-1) の近似の程度とが明 らかとなり, 前に述べた仮定がほぼ妥当であるといい得 るわけである。

\section{写真-1}

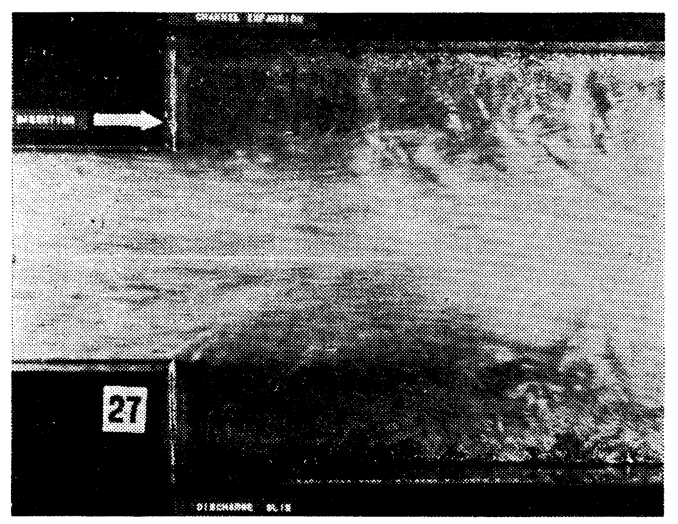

図一28 Velocity distribution in the mixing region.

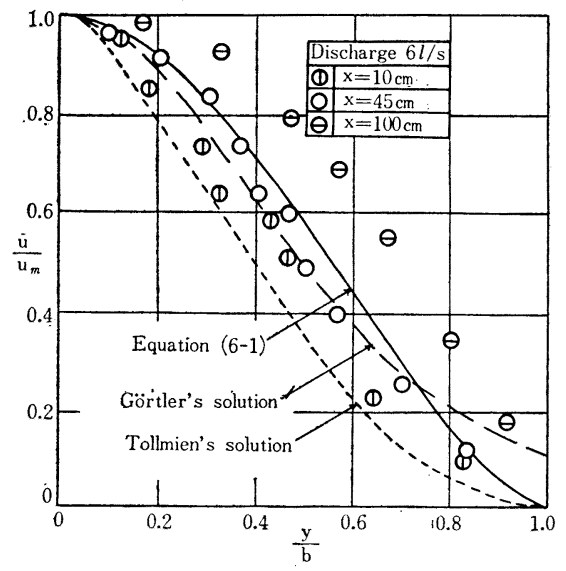

図-29 Relation between $l / \Delta B$ and $\beta_{*}$.

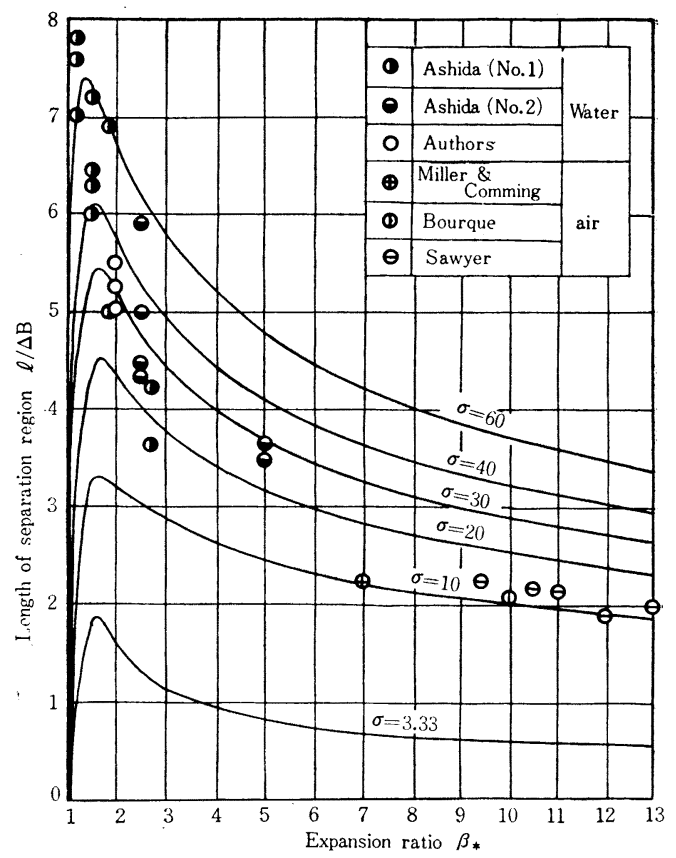

$x=100 \mathrm{~cm}$ における值は Reattaching 後の流速分布 を代表するもので, 下流水路側壁による運動量の反射の ため, 式 (6-1) からかなりずれている。

図一29 に示す実線は, 式 (6-20), (6-21) および式 (6-28) から得られた理論曲線を $\sigma$ をパラメーターとし て図示したもので，同時に従来の実験結果がプロットさ れている。わん曲した噴流では, その内縁の $\sigma$ の值が 2 次元理想噴流の場合の $\sigma=2 \sim 3$ にくらべて大きい值を 示しており，噴流の拡散が大きく制約されていることが わかる。これは側壁の噴流拡散の拘束効果に加えて, 噴 流わん曲の遠心力による抑制効果があるためと考えられ る。 $\beta_{*}$ が無限大のとき, $\sigma$ は $2 \sim 3$ の值となるはずであ るが, 図一29 では $\beta_{*}=7 \sim 13$ の範囲でほぼ 10 と評価 される。 $\beta_{*}$ が大きい急拡部では側壁による拘束は非常 
に小さく，わん曲による抑制効果が卓越していると考え られるから，わん曲による抑制効果はほぼ $\sigma=10$ とみて よい。 $\beta_{*}$ が小さくなると，この抑制効果に側壁による 拘束効果が加わって $\sigma$ は急激に増大する。しかしなが ら，。の急激な増大はたんに上に述べた拘束効果のみに 起因するものではなく， $\beta_{*}$ が小になればなるほど, 式 (6-11) に示した近似が実際現象 と離れていくことにも 関係があると思われる。すなわち， $\beta$ *が小さい場合に は, Reattaching するときの流速分布は Zone of flow establishment の領域にあるから，さきに述べたような 取り扱いは不可能となる。したがって $\beta_{*}$ が小さい場合 には, 図一26 の流速分布を Potential core を含んだ形 にするとともに, 他の条件も変える必要がある。しかし ながら, 拘束倸数 $\sigma$ を一の実験定数と考えて上のよう な取り扱いを行なうことも，害用的な立場から有用な一 つの方法であると考えられる。

\section{7. 結言}

本研究では, 水路急変部における遷移流の水理学的特 性を明らかにするための第一歩として, 水路幅が急激に 拡大寸る開水路の遷移現象について, とくに遷移の分 類, 遷移水面形状およびェネルギー損失を一次元解析に よって明らかにするとともに, 常流遷移について噴流理 論を応用し, 急拡部近傍の流速分布およびはく離領域の 長さを理論的に考察し, 実験的に検討を加えた。その結 果明らかにされた事実はつぎのとおりである。

(i ) 開水路急拡部における遷移現象については, 流量と勾配との関係によって 9 種類のものが考えられ, 下流下位によって常流遷移 (Submerged transition), 射流遷移(Shooting transition)および両者の遷移領域に おける限界流に近い不安定な遷移 (Unstabletransition) とに分類され，それぞれの限界は水路幅拡大比 $\beta_{*}$ と下 流の Froude 数 $F r_{2}$ が式 (3-10) および式 (3-11) を 満足する場合となる。

(ii) 急拡部の形状損失係数 $\zeta$ は $F r_{2}$ と $\beta_{*}$ とによ って変化し, 常流遷移では $F r_{2}$ の増加とともに急激に増 大し, 射流遷移では逆に減少するが, 同一の $F r_{2}$ に対し ては， $\beta_{*}$ の増加とともに急激に増大寸ることが明らか となった。

（iii）急拡部近傍における従来の流速分布の計算法は 逆流の影響を無視したものが多く，実際の現象を説明す るのに不十分であった。本研究では, はく離領域内に平 均化した等逆流領域を考えることにより, 逆流の影響を 考慮した場合の流速分布計算の可能性が明らかにされ た。

（iv）噴流挔散に対する下流水路側壁による拘束効果 を表わす指標として mean confine parameter $\sigma_{m}$ を導 大し, さらに混合領域内における流速分布を仮定するこ
とによって，はく離領域の長さに関する一つの計算法が 得られた。実験の結果， $\sigma_{m}$ の值は理想噴流の場合 $2 \sim 3$ であるが, 流下距離の増大とともに側壁による拘束効果 が大きくなり，平均して 4〜6 であることが明らかにさ れた。

(v) 前項は急拡部下流の両側に形成されるはく離領 域を平均化して対称な噴流拡散を対象としたものである が，実際の水流ではそのほとんどが非対称のはく離領域 を形成する。著者らはこれを下流水路側壁に流れが引き 寄せられる, いわゆる Coanda effectによるものと考え, 噴流のわん曲による遠心力の噴流拡散に対する抑制効果 と逆流補給に関する側壁の拘束効果とを, 実験定数であ る拘束係数 $\sigma$ の増加によって説明した。実験の結果, 拡 大比 $\beta_{*}$ が比較的大きく 7 以上の範囲では $\sigma=10$, 抗大 比が小さい範囲では $\sigma=30$ ６0 であると評価された。

以上のような考察および実験をすすめた結果, 一次元 的運動量解析と噴流理論とを適用することによって, 急 拡部における遷移流の水理学的特性の概略が説明できた と考えられる。しかしながら, 本研究は急拡部遷移流の もつ水理学的特性に関する研究の第一歩であり, 3 次元 的な水理現象の考慮, 拡大比 $\beta_{*}$ が小さい場合の噴流拡 散や Reattaching の特性および Reattaching した後の 流れの水理学的特性の解明など, 今後さらに理論的実験 的検討を加えて水理構造物における急変部設計に合理的 指針を得るよう努力すべきであると考えている。

最後に, 本研究を遂行するにあたり終始有益な助言を いただいた岩佐義朗教授ならびに劦力をいただいた大学 院学生河合怐二君 (現, 水資源開発公団) に憬く感謝す る次第である。

\section{参 考 文 献}

1) Hunter Rouse, B.V. Bhoota and En-Yun Hsu : Design of channel expansions, Trans. ASCE, Vol. 116, 1951.

2) F. Engelund and J. Munch-Pertersen : Ecoulement permanant dans les canaux convergents et divergents, La Houille Blanche, Aout, 1953.

3) G. Formica : Esperienze preliminari sulle perdite di carico nei canali, dovute a cambiamenti di sezione, L'Energia Elettrica, Vol. 32, 1955.

4）芦田和男：河川改修に伴なう断面急変部の水理とその適 用に関する研究, 学位論文, 昭和 36 年 7 月

5）芦田和男・宮井 宏: 断面变化部における河床变動に関 する研究 (II), 断面急拡部の砂堆の運動, 京都大学防災 研究所年報, 第 7 号, 昭和 38 年

6) H. Tults : Flow expansion and pressure recovery in fluids, Proc. ASCE; Vol. 80, 1954.

7）松下 玄: 開水路常流の流れ, 農業土木研究, 第 25 巻, 昭和 32 年 8 月

8) C. Jeager : Engineering Fluid Mechanics, Blackie \& Sons, London, 1956.

9) M.L. Albertson, Y.B. Dai, R.A. Jensen and H. Rouse : Diffusion of submerged jets, Trans. ASCE, Vol. 115, 1948.

10) W. Tollmien : Berechung turbulenter Ausbreitungs vorgänge, ZAMM, Vol. 6, 1926. 
11) A. Keuthe : Investigations of the turbulent mixing region formed by jets, Journal of Fluid Mechanics, Vol. 2, 1935.

12) E. Förthmann : Über turbulente Strahlausbreitung, Ing.-Arch, 5, 42, 1934.

13）佐藤清一・細井正延：噴流に関する研究 1, 土木研究所 報告, 81 号, 昭和 26 年

14）岩崎敏夫・千秋信一：静水中に落下する噴流の実験, 土 木学会誌, 38 巻 8 号, 昭和 28 年

15) H. Schlichting: Über das ebene Windschattenproblem, Ing.-Arch, 5, 533, 1930.

16) G.N. Abramovich: The theory of turbulent jets, The MIT Press Cambridge Massachusetts, 1963.

17) B.G. Newman: The deflection of plane jets by ad- jacent boundaries-Coanda effect, Boundary layer and flow control, London Pergamon Press, 1963.

18) C. Bourque and B.G. Newman : Reattachment of a two-dimensional incompressible jet to an adjacent flat plate, Aero, Quart, 1960.

19) J.I. Dodds : Ph. D. Thesis, Cambridge University, 1960.

20) R.A. Sawyer: The flow due to a two-dimensional jet issuing parallel to a flat plate, Journal of Fluid Mechanics, Vol. 9, 1960.

21) H. Görtler: Berechnung von Aufgaben der freien Turbulenz auf Grund eines neuen Naherungsansatzes, ZAMM, 22, 5, 1942.

(1965.9.13 - 受付) 